Firdaus Su'udiah. M.Pd

\title{
PENDIDIKAN IPS SD \\ KELAS AWAL
}


PENDIDIKAN IPS SD KELAS AWAL

Penulis

Editor layout

Penerbit

Alamat

ISBN
: Firdaus Su'udiah, M.Pd

: Septi Budi Sartika, M.Pd

: Umsida Press

: Jalan Mojopahit 666 B Sidoarjo 
Kualitas suatu negara salah satunya dilihat dari kualitas sumber daya manusia (SDM) yang dimilikinya. Pendidikan memegang peran penting untuk meningkatkan kualitas SDM di suatu negara. Melalui pendidikan, diharapkan setiap manusia akan mampu menggali potensi dirinya sehingga dapat menjadi manusia yang beriman dan bertakwa kepada Tuhan Yang Maha Esa, berakhlak mulia, sehat, berilmu, cakap, mandiri, kreatif, serta menjadi warga negara yang demokratis dan bertanggung jawab sesuai dengan UU Sisdiknas No. 20 Tahun 2003.

Pendidikan yang berkualitas dapat dicapai melalui aktivitas-aktivitas pembelajaran yang bermutu, salah satunya pembelajaran pendidikan IPS. Anggapan bahwa IPS kurang bermanfaat dibandingkan mata pelajaran lain seperti IPA dan matematika tentu persepsi yang salah. Pandangan tersebut harus diubah karena IPS sama pentingnya dan sama bermanfaatnya dengan mata pelajaran lainnya.

Pendidikan IPS di sekolah dasar harus dikemas dan disajikan dengan baik agar para siswa semakin tertarik mempelajari IPS dan merasakan kebermanfaatannya dalam kehidupan sehari-hari. Buku ini menyajikan materi tentang pendidikan IPS SD kelas awal sehingga dapat dijadikan salah satu acuan bagi mahasiswa maupun guru dalam membelajarkan IPS pada SD kelas awal.

Ibarat tak ada gading yang tak retak, demikian pula buku ini. Meskipun penulis telah berusaha menyajikan tulisan ini sebaik mungkin, tentu masih terdapat banyak kekurangan. Oleh sebab itu, masukan dari pembaca sangat diharapkan oleh penulis guna perbaikan buku ini ke depannya. semoga buku ini bisa bermanfaat bagi pembaca dan memberikan kontribusi untuk kemajuan pendidikan negeri kita tercinta, Indonesia. Amin.

Penulis

DAFTAR ISI 
BAB 1 Hakikat Ilmu Pengetahuan Sosial di Sekolah Dasar

a. Pengertian Pendidikan IPS

b. Dimensi Pendidikan IPS

c. Tujuan Pendidikan IPS

BAB 2 Esensi Kurikulum IPS SD Kelas Awal

a. Fakta, Konsep, dan Generalisasi

b. Contoh Keterkaitan Fakta, Konsep, dan Generalisasi pada Pendidikan IPS SD Kelas Awal

BAB 3 Tahap Perkembangan Kognitif SD Kelas Awal

a. Tahapan Menurut Piaget

b. Tahapan Menurut Brunner

c. Tahapan Menurut Ahli Lainnya

BAB 4 Metode dan Model Pembelajaran IPS SD

a. Metode-metode Pembelajaran IPS SD

b. Model-model Pembelajaran IPS SD

BAB 5 Media Pembelajaran IPS SD

a. Pengertian Media Pembelajaran

b. Macam-macam Media Pembelajaran

c. Pertimbangan Pemilihan Media Pembelajaran

BAB 6 Penilaian Pembelajaran IPS SD Kelas Awal

a. Pengertian Penilaian Pembelajaran

b. Bentuk Penilaian Pembelajaran

c. Contoh Penilaian Pembelajaran IPS SD Kelas Awal

BAB 7 Kedudukan IPS SD Kelas Awal pada Kurikulum 2013

a. Perbedaan IPS SD Kelas Awal pada KTSP dan Kurikulum 2013

Biodata Penulis

Daftar Pustaka 


\section{HAKIKAT ILMU PENGETAHUAN SOSIAL DI SEKOLAH DASAR}

Bab ini memuat bahan ajar tentang hakikat IPS di Sekolah Dasar (SD). Materi pada bab ini meliputi pengertian, dimensi, dan tujuan IPS. Penulisan bab ini bertujuan agar pembaca mampu:

1. Menjelaskan pengertian pendidikan IPS

2. Membedakan ilmu sosial dengan ilmu pengetahuan sosial

3. Menguraikan dimensi-dimensi pada pendidikan IPS

4. Memberi contoh setiap dimensi pada pendidikan IPS

5. Menganalisis tujuan-tujuan pendidikan IPS

6. Mengemukakan alasan urgensi pendidikan IPS di SD

\section{A. PENGERTIAN IPS}


Istilah Ilmu Pengetahuan Sosial (IPS) di Indonesia secara resmi mulai dipergunakan sejak tahun 1975. Di Amerika Serikat, IPS dikenal sebagai social studies. Secara sederhana IPS dapat diartikan sebagai sebuah kajian tentang masyarakat secara terpadu. Kajian ini dapat dilihat dari berbagai sudut pandang ilmu sosial, seperti ekonomi, geografi, sosiologi, sejarah, antropologi politik-pemerintahan, dan psikologi sosial.

Berikut pengertian IPS yang dikemukakan oleh para ahli.

a. Nu'man Soemantri menyatakan bahwa IPS merupakan penyederhanaan ilmu-ilmu sosial untuk pendidikan tingkat SD, SMP, hingga SMA. Artinya, tingkat kesulitan ilmu-ilmu sosial yang biasanya dipelajari di universitas disesuaikan dengan kematangan berpikir -siswi sekolah dasar dan lanjutan, serta perpaduan segala materi ilmu-ilmu sosial dan kehidupan masyarakat sehingga menjadi pelajaran yang mudah dimengerti.

b. S. Nasution mengartikan IPS sebagai paduan atau gabungan sejumlah mata pelajaran sosial. IPS merupakan bagian kurikulum sekolah yang berhubungan dengan peran manusia dalam masyarakat.

c. Moeljono Cokrodikardjo mendefinisikan IPS sebagai pewujudan dari suatu perdekatan interdisipliner dari ilmu sosial. IPS merupakan integrasi dari berbagai cabang ilmu sosial yang disederhanakan agar mudah dipelajari dan mencapai tujuan pembelajaran.

Dari berbagai pengertian tersebut, dapat disimpulkan bahwa IPS merupakan mata pelajaran yang memadukan berbagai cabang ilmu sosial guna mempelajari dan menelaah berbagai permasalahan sosial di masyarakat. Berbagai macam ilmu sosial antara lain: sosiologi, ekonomi, geografi, sejarah, psikologi sosial, politik dan pemerintahan, hukum, manajemen, dan antropologi budaya.

Sosiologi berkaitan dengan sifat, perilaku, dan perkembangan masyarakat. Ekonomi menitikberatkan pada pemenuhan kebutuhan 
manusia mulai dari produksi, distribusi, hingga konsumsi. Geografi berkaitan dengan manusia, flora fauna, dan faktor alam/lingkungan.

Sejarah berkenaan dengan peristiwa yang telah terjadi di masa lalu. Psikologi sosial membahas aspek kejiwaan manusia dalam kehidupan bermasyarakat. Politik pemerintahan membahas kebijaksanaan dan kesejahteraan sosial, serta aspek kenegaraan.

Ilmu hukum mempelajari tentang norma, peraturan, dan hukum. Manajemen berkaitan tentang pengelolaan, pengorganisasian, pengaturan, dan sebagainya. Antropologi budaya berkenaan dengan kebudayaan.

IImu Pengetahuan Sosial (IPS) memiliki perbedaan dengan ilmu sosial. Perbedaan antara IImu Sosial dengan IPS sebagai berikut:

1. Pengertian

Ilmu sosial adalah semua bidang ilmu yang mempelajari manusia sebagai anggota masyarakat. Sedangkan IImu Pengetahuan Sosial adalah mata pelajaran yang memadukan berbagai cabang ilmu sosial guna mempelajari dan menelaah berbagai permasalahan sosial di masyarakat

2. Objek

Ilmu sosial mengkaji berbagai aspek kehidupan manusia secara terpisah sehingga melahirkan satu bidang ilmu. IImu Pengetahuan Sosial mengkaji aspek kehidupan manusia secara terpadu berdasarkan satu kesatuan gejalah/masalah sosial.

3. Tujuan

IImu sosial bertujuan menciptkan tenaga ahli pada bidang ilmu sosial. Ilmu Pengetahuan Sosial bertujuan membentuk warga negara yang memiliki kemampuan sosial, yakin akan kehidupannya sendiri di tengah-tengah kekuatan fisik dan sosial, sehingga mampu menjadi anggota masyarakat yang baik dan bertanggung jawab.

4. Pendekatan 
Ilmu sosial menggunakan pendekatan disipliner. IImu Pengetahuan Sosial menggunakan pendekatan interdisipliner atau multidisipliner.

5. Tempat Pembelajaran

IImu sosial dipelajari dan dikembangkan pada tingkat Perpendidikan Tinggi. Ilmu Pengetahuan Sosial diajarakan pada jenjang sekolah dasar hingga menengah, yaitu SD-SMA.

\section{B. DIMENSI PENDIDIKAN IPS}

IPS memiliki 4 dimensi, yaitu dimensi pengetahuan, keterampilan, nilai dan sikap, serta tindakan. Berikut pemaparannya.

1. Dimensi Pengetahuan (Knowledge)

Pada dimensi pengetahuan (knowledge) sebaiknya mencakup fakta, konsep, dan generalisasi. Fakta adalah data yang spesifik tentang peristiwa, objek, orang dan hal-hal yang terjadi. diharapkan dapat mengenal berbagai jenis fakta khususnya yang terkait dengan kehidupan sosial kemasyarakatan melalui pembelajaran IPS. Fakta disajikan untuk para sesuai dengan usia dan tingkat kemampuan berpikirnya.

Konsep merupakan kata-kata atau frase yang mengelompok, berkategori, dan memberi arti terhadap kelompok fakta yang berkaitan. Konsep merujuk pada pelabelan suatu hal atau unsur kolektif.

Generalisasi adalah suatu pernyataan yang terdiri dari dua atau lebih konsep yang saling terkait. Kompleksitas isi generalisasi disesuaikan dengan tingkat perkembangan .

2. Dimensi Keterampilan (Skills)

Dimensi keterampilan terdiri dari keterampilan meneliti, berpikir, partisipasi sosial, dan berkomunikasi. Berikut penjelasannya.

a. Keterampilan Meneliti 
Keterampilan meneliti diperlukan untuk mengumpulkan dan mengolah data. Secara umum, aktivitas penelitian sebagai berikut:

1. Mengidentifikasi dan mengungkapkan masalah atau isu

2. Mengumpulkan dan mengolah data

3. Menafsirkan data

4. Menganalisis data

5. Menilai bukti-buki yang ditemukan

6. Menyimpulkan

b. Keterampilan Berpikir

Sejumlah keterampilan berpikir memiliki peran terhadap pemecahan masalah dan partisipasi dalam kehidupan masyarakat secara efektif. Untuk mengembangkan keterampilan berpikir pada diri, perlu ada latihan dan pembiasaan melalui pemberian masalah yang harus diselesaikan oleh. Contoh keterampilan berpikir yang dapat dilatih oleh guru, antara lain:

1. Mengkaji dan menilai data secara kritis

2. Merumuskan faktor sebab dan akibat

3. Memprediksi hasil dari sesuatu kegiatan atau peristiwa

4. Menyarankan apa yang akan ditembulkan dari suatu peristiwa atau perbuatan

5. Berspekulasi tentang masa depan

6. Menyarankan berbagai solusi alternatif

7. Mengajukan pendapat dan perspektif yang berbeda

c. Keterampilan Partisipasi Sosial merupakan bagian dari kelompok masyarakat sehingga ia harus belajar bagaimana hidup bermasyarakat. Keahlian bekerja dalam kelompok sangat penting karena dalam kehidupan bermasyarakat begitu banyak orang menggantungkan hidup 
melalui kelompok. Beberapa keterampilan partisipasi sosial yang perlu dibelajarkan oleh guru meliputi:

Mengidentifikasi akibat dari perbuatan dan pengaruh ucapan terhadap orang lain

1. Menunjukkan rasa hormat dan perhatian kepada orang lain

2. Berbuat efektif sebagai anggota kelompok

3. Mengambil berbagai peran kelompok

4. Menerima kritik dan saran

d. Keterampilan Berkomunikasi

Pada pembelajaran IPS, pengembangan aspek berkomunikasi sangat penting. Setiap perlu diberi kesempatan untuk mengungkapkan pemahaman dan perasaannya dengan jelas, efektif, dan kreatif. Selain menggunakan bahasa tulis dan lisan telah sebagai alat berkomunikasi yang paling sering digunakan, guru juga dapat mendorong para untuk mengungkapkan gagasannya dalam bentuk lain, seperti dalam film, drama, seni (suara, tari, lukis), pertunjukkan, foto, bahkan dalam bentuk peta. Para hendaknya dimotivasi agar menjadi pembicara dan pendengar yang baik.

\section{Dimensi Nilai dan Sikap (Value and Attitude)}

Pada hakikatnya, nilai merupakan sesuatu yang berharga. Nilai merupakan prinsip atau keyakinan dalam diri seseorang atau kelompok masyarakat tertentu ketika berpikir atau bertindak. Sedangkan sikap merupakan kemampuan mengembangkan dan menerima keyakinan, kecenderungan, atau pandangan tertentu.

Nilai tidak selalu berlaku universal. Bisa jadi nilai tertentu dianut oleh seseorang, tetapi tidak dianut oleh orang yang lain. Secara umum, nilai dipelajari melalui interaksi dan komunikasi antar individu dalam kelompok seperti keluarga, himpunan keagamaan, kelompok 
masyarakat atau persatuan dari orang-orang dengan tujuan yang sama.

Nilai dapat dibedakan menjadi dua, yaitu nilai substantif dan nilai prosedural. Nilai substantif umumnya merupakan hasil belajar seseorang sehingga ia meyakini dan memegang teguh nilai tersebut, bukan sekedar menanamkan informasi semata. Masing-masing orang memiliki pendapat dan keyakinan yang berbeda sesuai dengan apa yang dia yakini.

Dengan belajar nilai substantif, akan menyadari bahwa dirinya memiliki nilai tertentu. Guru sebagai fasilitator pembelajaran harus menjelaskan bahwa siswa dalam kelas membawa nilai yang beragam sesuai dengan latar belakang keluarga, agama, atau budaya. Melalui pembelajaran IPS, diharapkan dapat memiliki kesempatan untuk mengungkapkan, merefleksi, dan mengekspresikan nilai yang dianutnya.

Proses ini tergantung pada nilai-nilai prosedural di kelas. hendaknya memiliki hak menentukan nilai mana yang akan dianut tanpa paksaan atau menangguhkan keputusan dan tetap tidak mengambil keputusan. Dengan kata lain, hendaknya didorong untuk bersiap diri membenarkan posisinya, mendengarkan kritikan yang ditujukan terhadap dirinya dan atau mengubah keputusannya bila ada pertimbangan lain.

Nilai-nilai prosedural yang perlu dilatih atau dibelajarkan antara lain nilai kemerdekaan, toleransi, kejujuran, menghormati kebenaran dan menghargai orang lain. Nilai-nilai kunci ini merupakan nilai yang menyokong masyarakat demokratis, seperti: toleran terhadap pendapat yang berbeda, menghargai bukti yang ada, kerja sama, dan menghormati pribadi orang lain.

\section{Dimensi Tindakan (Action)}

Dimensi tindakan memungkinkan anak menjadi siswa yang aktif. Mereka pula dapat belajar secara konkret dan praktis. dapat belajar 
dari apa yang diketahuinya tentang isu-isu dan permasalahan sosial, lalu mencoba mencari alternatif jalan keluarnya. Hal ini membuat belajar menjadi warga negara yang baik dan mampu berkontribusi di masyarakat.

Pembelajaran dimensi tindakan dapat dilakukan pada semua jenjang. Ada tiga model aktivitas dimensi tindakan sebagai berikut: 1) Percontohan kegiatan dalam memecahkan masalah di kelas seperti cara berorganisasi dan bekerja sama; 2) Berkomunikasi dengan anggota masyarakat dapat diciptakan; dan 3)Pengambilan keputusan dapat menjadi bagian kegiatan kelas, khususnya pada saat diajak untuk melakukan inkuiri. (Susanto, 2016)

\section{TUJUAN PENDIDIKAN IPS}

Tujuan berarti sesuatu yang hendak dicapai atau diharapkan. Kenworthy dalam Depdiknas (2007) menyatakan ada 3 karakteristik tujuan IPS, yaitu pendidikan kemanusiaan, kewarganegaraan, dan intelektual. IPS diharapkan mampu membantu anak memahami pengalamannya dan menemukan makna dalam kehidupannya. juga harus dipersiapkan untuk berperan aktif dalam dinamika kelompok kehidupan bermasyarakat. Siswa hendaknya selalu berupaya menjadi warga negara yang bertanggung jawab dan setia. Selain itu, para siswa juga akan dihadapkan dengan berbagai permasalahan di masyarakat. Siswa berupaya memecahkan permasalahan tersebut dan mengambil keputusan sendiri.

Pada hakikatnya tujuan pendidikan IPS di sekolah dasar untuk mengembangkan potensi siswa agar peka terhadap masalah sosial yang terjadi dimasyarakat, memiliki sikap mental positif terhadap perbaikan segala ketimpangan yang terjadi, dan terampil mengatasi setiap masalah yang terjadi sehari-hari baik yang menimpa dirinya maupun masyarakat. Hasan dalam Sapriya (2006: 15) menyatakan tujuan pendidikan IPS dapat dikelompokkan dalam tiga kategori, yaitu pengembangan intelektual siswa, pengembangan rasa 
tanggung jawab siswa sebagai anggota masyarakat dan bangsa, serta pengembangan diri siswa sebagai pribadi. Sementara itu, tujuan IPS dalam Permendiknas No. 22 Tahun 2006 Tentang Standar Isi yaitu siswa memiliki kemampuan sebagai berikut:

1. Mengenal konsep-konsep yang berkaitan dengan kehidupan masyarakat dan lingkungannya.

2. Memiliki kemampuan dasar untuk berpikir logis dan kritis, rasa ingin tahu, inkuiri, memecahkan masalah, dan keterampilan dalam kehidupan sosial.

3. Memiliki kesadaran terhadap nilai sosial dan kemanusiaan.

4. Memiliki kemampuan berkomunikasi, bekerjasama, dan berkompetisi dalam masyarakat yang majemuk, ditingkat lokal, nasional dan global.

Sapriya (2006: 33) menyebutkan tujuan IPS sebagai berikut:

1. Mengajarkan konsep-konsep dasar sejarah sosiologi, antropologi, ekonomi, dan kewarganegaraan melalui pendekatan pedagogis, dan psikologis.

2. Mengembangkan kemampuan berpikir kritis, kreatif, inkuiri, dan keterampilan sosial.

3. Membangun komitmen dan kesadaran terhadap nilai-nilai sosial dan kemanusiaan.

4. Meningkatkan kerja sama dan kompetensi dalam masyarakat yang heterogen baik secara nasional maupun global.

Pendidikan IPS menurut Kurikulum Berbasis Kompetensi (KBK) 2004 bertujuan untuk: 1) mengembangkan pemahaman tentang konsep-konsep dasar ilmu-ilmu sosial melalui pendekatan psikologis dan pedagogis; 2) mengambangkan kemampuan berpikir kritis, kreatif, inkuiri, dan pemecahan masalah serta keterampilan sosial; 3) menanamkan kesadaran dan loyalitas terhadap sistem nilai dan norma-norma sosial; 4) meningkatkan kemampuan berkolaborasi 
dan berkompetisi secara sehat dalam kehidupan masyarakat yang sarat dengan keanekaragaman, baik dalam skala nasional maupun internasional.

Sementara itu, Kurikulum Tingkat Satuan Pendidikan (KTSP) 2006 merumuskan pendidikan IPS bertujuan agar siswa memiliki kompetensi berikut ini:

1. Mengenal konsep-konsep yang berkaitan dengan kehidupan masyarakat dan lingkungannya

2. Memiliki kemampuan dasar untuk berpikir logis dan kritis, rasa ingin tahu, inkuiri, memecahkan masalah, dan keterampilan dalam kehidupan sosial

3. Memiliki komitmen dan kesadaran terhadap nilai-nilai sosial dan kemanusiaan

4. Memiliki kemampuan berkomunikasi, bekerjasama dan berkompetisi dalam masyarakat yang majemuk, di tingkat lokal, nasional, dan global.

Dari beberapa pemaparan di atas, dapat dikatakan bahwa pendidikan IPS di Sekolah Dasar (SD) bertujuan agar siswa mampu berpikir kritis, logis, dan terampil dalam menyelesaikan permasalahan kehidupan sosial, serta mengkomunikasikannya dengan percaya diri. Selain itu, IPS di SD juga bertujuan sebagai bekal bagi siswa untuk melanjutkan pendidikan ke jenjang selanjutnya yang lebih tinggi. 


\section{RANGKUMAN}

IPS merupakan mata pelajaran yang memadukan berbagai cabang ilmu sosial guna mempelajari dan menelaah berbagai permasalahan sosial di masyarakat. Esensi materi pada mata pelajaran IPS di SD meliputi aspek geografi (manusia, tempat, dan lingkungan), Sejarah (waktu dan perubahan), Sosiologi (sistem sosial dan budaya) serta Ekonomi (perilaku ekonomi dan kesejahteraaan).

Ada empat dimensi dalam IPS, yaitu dimensi pengetahuan, dimensi keterampilan, dimensi nilai dan sikap, serta dimensi tindakan. Dimensi pengetahuan memuat fakta konsep dan generalisasi. Dalam dimensi keterampilan terdapat keterampilan meneliti, keterampilan berpikir, keterampilan partisipasi sosial, dan keterampilan berkomunikasi. Sementara itu, dimensi nilai dan sikap memuat nilai substantif dan nilai prosedural.

Pendidikan IPS di Sekolah Dasar (SD) bertujuan agar siswa mampu berpikir kritis, logis, dan terampil dalam menyelesaikan permasalahan kehidupan sosial, serta mengkomunikasikannya dengan percaya diri. Selain itu, IPS di SD juga bertujuan sebagai bekal bagi siswa untuk melanjutkan pendidikan ke jenjang selanjutnya yang lebih tinggi. 


\section{BAB 2}

\section{ESENSI KURIKULUM IPS SD KELAS AWAL}

Bab ini memuat bahan ajar tentang esensi kurikulum IPS SD kelas awal, yang meliputi fakta, konsep, generalisasi, dan contohnya pada pendidikan IPS SD kelas awal. Setelah mempelajari bab ini, pembaca diharapkan mampu:

1. Menjelaskan pengertian fakta, konsep, dan generalisasi

2. Menganalisis keterkaitan fakta, konsep, dan generalisasi dalam pendidikan IPS

3. Mengidentifikasi fakta, konsep, dan generalisasi pada kurikulum pendidikan IPS SD kelas awal

4. Memberi contoh keterkaitan fakta, konsep, dan generalisasi pada kurikulum pendidikan IPS SD kelas awal 


\section{A. FAKTA, KONSEP, DAN GENERALISASI}

Dalam pembelajaran IPS, anak belajar mengenali, memahami, dan menganalisis berbagai isu sosial. Secara sederhana, isu sosial dapat dimaknai sebagai kabar/berita peristiwa tentang aktivitas manusia yang terjadi di masyarakat tetapi masih belum jelas asal usul dan kebenarannya. Peristiwa kemudian diamati guna memastikan apakah hal tersebut benar-benar terjadi atau hanya isu/kabar burung.

Peristiwa baik di masa kini maupun di masa lalu tetap harus diuji kebenarannya. Peristiwa yang benar-benar terjadi dapat dicari suatu fakta yang dapat diamati dan ditunjukkan secara jelas sebagai realita. Fakta terungkap dari pengamatan atas kenyataan, kenyataan lahir karena dukungan fakta. (Sardjiyo: 2009)

\section{Fakta}

Menurut KBBI, fakta adalah hal (keadaan, peristiwa) yang merupakan kenyataan; sesuatu yang benar-benar ada atau terjadi. Banks (1958:81) mengartikan fakta sebagai pernyataan positif dan rumusannya sederhana. Fakta juga merupakan data aktual, contohnya sebagai berikut.

a. Surabaya adalah ibukota provinsi Jawa Timur

b. Bumi berputar mengelilingi matahari

c. KTP termasuk dokumen diri

d. Indonesia merdeka pada tanggal 17 Agustus 1945

Sardjiyo (2009:2.8) menjelaskan bahwa fakta dapat menyebabkan lahirnya teori baru, menjadi alasan untuk menolak teori yang ada, bahkan mendorong untuk mempertajam rumusan teori yang telah ada. Oleh sebab itu, guru hendaknya berupaya menjelaskan pengertian fakta dengan cara sederhana. Guru dapat memberikan pertanyaan kepada siswa yang jawabannya berupa fakta. Contoh pertanyaan yang dapat diajukan guru sebagai berikut: 

a. Siapa nama Kepala Sekolah kita?
b. Berapa banyak yang absen hari ini?
c. Berapa banyak hari dalam satu minggu?

Siswa akan menjawab nama Kepala Sekolahnya pak Bakhtiar; ada tiga siswa yang absen; dan ada tujuh hari dalam satu minggu. Jawaban tersebut merupakan fakta. Melalui pertanyaan-pertanyaan yang dilontarkan guru, siswa akan menyadari bahwa fakta itu amat banyak. Fakta dapat berupa data maupun hasil pengamatan secara lebih khusus.

Meski demikian, fakta bukanlah tujuan akhir dalam pembelajaran IPS. Pengetahuan yang hanya bertumpu pada fakta memiliki keterbatasan. Hal tersebut disebabkan kemampuan kita untuk mengingat sangat terbatas. Selain itu, fakta bisa berubah sesuai dengan waktunya. Sebagai contoh perubahan cuaca suatu daerah, perubahan bentuk pemerintahan, perubahan pemimpin suatu kelompok, dan sebagainya. Fakta juga hanya berkenaan dengan situasi khusus. Oleh sebab itu, fakta hendaknya tidak dijadikan tujuan akhir dalam pembelajaran.

\section{Konsep}

Menurut Soedjadi (2000:14) pengertian konsep adalah ide abstrak yang dapat digunakan untuk mengadakan klasifikasi atau penggolongan yang pada umumnya dinyatakan dengan suatu istilah atau rangkaian kata. Sementara itu, menurut Kamus Besar Bahasa Indonesia (2007:588), konsep adalah gambaran mental dari objek, proses, atau apa pun yang ada di luar bahasa, yang digunakan oleh akal budi untuk memahami hal-hal lain.

Konsep merupakan suatu kesepakatan bersama untuk penamaan sesuatu dan merupakan alat intelektual yang membantu kegiatan berfikir dan memecahkan masalah. Sardjiyo (2009:2.9) mengartikan konsep sebagai pengungkapan abstrak yang digunakan 
untuk tujuan mengklasifikasikan atau mengkategorikan suatu kelompok dari suatu (benda), gagasan, atau peristiwa.

Dari pengertian tersebut dapat ditarik sebuah ke simpulan bahwa konsep mengandung atribut. Atribut adalah ciri yang membedakan tabel objek atau peristiwa atau proses dari obyek, peristiwa atau proses lainnya. Atribut dapat didasarkan atas fakta berupa informasi konkret yang dapat dibuktikan melalui laporan seseorang atau hasil pengamatan langsung. Laporan verbal, gambar-gambar, chart yang berisi data dapat digunakan untuk mengkomunikasikan atribut.

Menurut Womack (1970), selain memahami konsep yang dibangun berdasarkan pengenalan kita terhadap atribut kelas (penggolongan) dan simbol, juga penting memahami tingkat arti (level of meaning) dari sebuah konsep. la berpendapat bahwa sebuah konsep studi sosial merupakan kata atau sekumpulan kata (prosa) yang berkaitan dengan satu gambaran tertentu yang menonjol dan bersifat tetap (Certain, vakint, inalienable, features = tetap, menonjol, tak dapat dicabut). Untuk lebih menjelaskan pengertian tentang konsep, berikut ini dikemukakan beberapa sifatnya.

a. Konsep itu bersifat abstrak. la merupakan gambaran mental tentang benda, peristiwa, atau kegiatan. Misalnya, kita mendengat kata "kelompok", kita bisa membayangkan apa kelompok itu.

b. Konsep itu merupakan "kumpulan" dari benda-benda yang memiliki karakteristik atau kualitas secara umum.

c. Konsep itu bersifat personal, pemahaman orang tentang konsep "kelompok" misalnya mungkin berbeda dengan pemahaman orang lain.

d. Konsep dipelajari melalui pengalaman dengan belajar.

e. Konsep bukan persoalan arti kata, seperti didalam kamus. Kamus memiliki makna lain yang lebih luas. 
Konsep merupakan sesuatu yang penting untuk dipelajari karena akan membantu dalam beberapa hal seperti yang diungkapkan oleh De Cecco (dalam Husein Achmad, 1982). Kegunaan pemahaman terhadap konsep antara lain sebagai berikut.

a. Menghadapi lingkungan yang kompleks dan luas serta mengurangi kesulitan dalam menguasai fakta-fakta yang selalu bertambah.

b. Mengidentifikasikan dan mengindera macam-macam objek yang ada di sekeliling kita. Apabila seseorang mengidentifikasikan sesuatu benda, benda tersebut dimasukkan dalam kelas tertentu.

c. Mengurangi perlunya belajar mengulang-ulang hal baru yang sebenarnya merupakan atribut dan nilai atribut yang sama dengan konsep yang sudah diketahui. Dengan kata lain hal yang baru itu sudah termasuk dalam konsep tertentu.

d. Membantu memecahkan masalah dengan menempatkan masalah dalam klasifikasi yang benar. Dengan demikian kita memperoleh pemecahan bagaimana memproses masalah yang ada di hadapan kita.

e. Memungkinkan kita memberikan pengajaran yang lebih kompleks dan menerangkan secara lebih jelas.

f. Menggambarkan kenyataan dan dunia. Dengan melalui konsep seseorang diharapkan bisa berpikir atau melihat sesuatu yang berhubungan, menciptakan, dan melaksanakan segala sesuatu. Namun demikian kita harus berhati-hati terhadap konsep stereotipe, yaitu konsep yang didasarkan atas pengalaman-pengalaman yang keliru.

Agar siswa dapat memahami pengertian konsep-konsep IPS dengan lebih jelas dan memadai maka seorang guru hendaknya memperhatikan hal-hal penting dalam mengajarkan konsep-konsep IPS. Dalam hal ini Yelon (dalam Husein Achmad, 1982) 
mengemukakan bagaimana mengajar konsep yang baik sebagai berikut:

a. Merumuskan tujuan

Guru harus menetapkan tujuan tertentu untuk masing-masing mata pelajaran. Dalam mengajar konsep, guru hendaknya memberi kesempatan kepada untuk menggunakan kemampuannya dalam memberikan atau memilih contoh-contoh tentang konsep

b. Menyadari adanya pengetahuan prasyarat yang akan membantu pemahaman konsep

Syarat utama untuk mempelajari konsep adalah memilah-milah, yaitu membedakan antara obyek yang satu dengan obyek lainnya, antara simbol yang satu dengan simbol yang lain. Selanjutnya guru harus mengetahui pengetahuan prasyarat, yaitu bahwa harus mampu menunjukkan atribut definisi dan memahami konsep.

c. Menyajikan definisi dan contoh-contoh

Guru harus menyajikan definisi contoh-contoh. Sebab konsep akan mudah dipahami apabila apek yang relevan dengan stimulus jelas dan aspek yang tidak relevan dengan stimulus kurang jelas atau kurang tajam. Selain itu, konsep juga akan mudah dipahami jika guru banyak menggunakan contoh-contoh yang positif

Membentuk konsep merupakan tugas intelektual yang tidak mudah. Meski demikian, guru perlu menyadari bahwa telah belajar konsep sejak sebelum sekolah. Di sekolah, mereka belajar konsep yang simbolis atau abstrak.

Konsep akan mudah dipelajari jika diberikan contoh-contoh. Misalnya, siswa akan lebih mudah memahami konsep kota saat guru menyebutkan Jakarta, Surabaya, Malang, Bandung, Medan, Pekanbaru, dan lain-lain. Saat guru memberi contoh ayah, ibu, 
saudara, kakek, nenek, dan sebagainya, siswa akan segera memahami tentang konsep anggota keluarga. Dari berbagai pengertian dan contoh yang telah disebutkan, dapat disimpulkan bahwa konsep merupakan sekelompok objek yang telah dikategorikan, diklasifikasikan, dan diberi nama.

\section{Generalisasi}

Schuneke (1988:16) mengemukakan bahwa generalisasi merupakan abstraksi dan sangat terikat konsep. Generalisasi menghubungkan beberapa konsep sedemikian rupa sehingga terbentuk suatu pola hubungan yang bermakna dan menggambarkan hal yang lebih luas. Menurut Nursid Sumaatmadja (1980:83), generalisasi adalah hubungan dua konsep atau lebih dalam bentuk kalimat lengkap, yang merupakan pernyataan deklaratif dan dapat dijadikan suatu prinsip atau ketentuan dalam IPS.

Jadi dapat disimpulkan bahwa generalisasi merupakan pernyataan yang bersifat umum, tidak terikat pada situasi khusus, yang menunjukkan adanya hubungan di antara konsep. Seseorang dikatakan menyusun generalisasi, apabila orang itu menarik dua konsep atau lebih dengan sedemikian rupa sehingga saling berhubungan satu dengan lainnya. Untuk lebih jelasnya kita ambil contoh berikut. Ada ungkapan : "Makin primitif suatu masyarakat, lingkungan hidupnya akan makin mempengaruhi cara hidup masyarakat itu" kita menemukan paling sedikit tiga konsep, yaitu: (1) Masyarakat primitif; (2) Lingkungan hidup; (3) Cara hidup.

Generalisasi yang tidak menyebut orang, tempat atau benda adalah generalisasi yang baik. Dengan tidak menyebut orang, tempat, atau benda, abstraksi generalisasi yang kita buat makin tinggi. Selain itu, jika kita menyebut orang, tempat, atau benda, tingkat keberlakuannya menjadi sempit atau rendah. Generalisasi 
harus ditulis sedemikian rupa sehingga dapat mengaplikasikannya dalam berbagai situasi yang bagaimanapun juga.

Tabel berikut menyajikan perbandingan generalisasi dengan konsep, menurut Rochiati (2006:6).

\begin{tabular}{|l|l|}
\hline \multicolumn{1}{|c|}{ Generalisasi } & \multicolumn{1}{c|}{ Konsep } \\
\hline $\begin{array}{l}\text { Generalisasi adalah } \\
\text { prinsip-prinsip atau rules } \\
\text { (aturan) yang dinyatakan } \\
\text { dalam kalimat sempurna. }\end{array}$ & $\begin{array}{l}\text { Konsep bukan merupakan } \\
\text { prinsip dan dinyatakan tidak di } \\
\text { dalam kalimat yang sempurna. }\end{array}$ \\
\hline Generalisasi memiliki dalil. & Konsep tidak memiliki dalil. \\
\hline $\begin{array}{l}\text { Generalisasi adalah objektif } \\
\text { dan impersonal. }\end{array}$ & Konsep subjektif dan personal. \\
\hline
\end{tabular}

Rochiati dalam Jarotimec (1986:29) mengungkapkan adanya empat jenis generalisasi yang diperlukan dalam kajian sejarah dalam IPS, yaitu:

a. Generalisasi deskriptif

Contoh: Pada umumnya pusat-pusat kerajaan terletak di tepi sungai.

b. Generalisasi sebab akibat

Contoh: Di dalam revolusi, apabila golongan ekstrem berhasil merebut kekuasaan maka akan berlangsung pementahan teror.

c. Generalisasi acuan nilai

Contoh: Raja adil raja disembah, raja lalim raja disanggah.

d. Generalisasi prinsip universal

Contoh: Kapasitas sebuah bangsa untuk memodelisasikan diri tergantung pada potensi sumber daya alamnya, kualitas manusianya dan orientasi nilai para pelaku sejarahnya.

B. CONTOH KETERKAITAN FAKTA, KONSEP, DAN GENERALISASI PADA PENDIDIKAN IPS SD KELAS AWAL 
Fakta, konsep, dan generalisasi sangat erat kaitannya dalam dimensi pengetahuan. Ketiganya juga memiliki hubungan timbal balik dengan bahan ajar yang akan digunakan untuk mencapai tujuan pembelajaran IPS. Guru sebagai seseorang yang paling dekat dengan tentu mengetahui kemampuan masing-masing nya. Oleh sebab itu, guru harus mampu menyusun bahan ajar yang sesuai dan menyampaikannya kepada melalui kegiatan pembelajaran yang tepat.

Berikut ini disajikan contoh keterkaitan fakta, konsep, dan generalisasi pembelajaran IPS di kelas awal. Contoh berikut ini untuk kelas 3 semester 1 .

1. Tema : Lingkunganku

2. Subtema : Lingkungan rumah

3. Tujuan Pembelajaran

a. Menjelaskan pengertian lingkungan alam

b. Menjelaskan pengertian lingkungan buatan

c. Menjelaskan pengertian rumah

d. Menyebutkan benda-benda dari alam yang ada di sekitar rumah

e. Menyebutkan benda-benda buatan manusia yang ada di sekitar rumah

f. Menceritakan pentingnya lingkungan alam dan buatan bagi manusia

4. Fakta

a. Daftar benda-benda/barang-barang yang berasal dari alam dan buatan manusia

b. Cerita tentang pengalaman sebagai anggota keluarga di rumah

c. Daftar tugas harian di rumah

d. Hak dan kewajiban anggota keluarga terhadap lingkungan alam dan buatan 
5. Konsep

Rumah, lingkungan alam, lingkungan buatan, lingkungan sosial, kedudukan dan peran, pernikahan, rumah tangga, tata krama, sopan santun, dan sebagainya.

6. Generalisasi

a. Di sekitar rumah terdapat lingkungan alam dan buatan

b. Setiap anggota keluarga di rumah harus bertanggung jawab terhadap kebersihan dan keindahan lingkungan rumah sesuai dengan perannya masing-masing.

BAB 3

TAHAP PERKEMBANGAN KOGNITIF SISWA SD KELAS AWAL 
Materi pada bab ini berkaitan dengan tahap perkembangan kognitif siswa SD kelas awal. Setelah materi ini selesai dipelajari, diharapkan pembaca mampu:

1. Menjelaskan tahap-tahap perkembangan kognitif siswa SD menurut Piaget

2. Menjelaskan tahap-tahap perkembangan kognitif siswa SD menurut Brunner

3. Menjelaskan tahap-tahap perkembangan kognitif siswa SD menurut ahli lainnya

4. Menentukan tahap perkembangan kognitif siswa SD kelas awal menurut berbagai ahli

5. Merumuskan hubungan tahap perkembangan kognitif dengan pembelajaran pendidikan IPS SD kelas awal

\section{A. TAHAPAN MENURUT PIAGET}


Perkembangan kognitif menurut Piaget terdiri dari 4 tahap/periode, yaitu sensorimotor, praoperasional, operasional konkret, dan operasional formal. Berikut penjelasan masing-masing periode/tahapan perkembangan.

\section{Tahap Sensorimotor}

Tahap sensorimotor adalah tahap pertama dari 4 tahapan yang dirumuskan Piaget. Piaget berpendapat bahwa bayi lahir dengan sejumlah refleks bawaan serta memiliki dorongan untuk mengeksplorasi dunianya. Skema awalnya dibentuk melalui diferensiasi refleks bawaan tersebut.

Pada periode ini, dominasi tingkah laku anak ada pada gerakan-gerakan refleksnya atau bersifat motorik. Penyebab gerakan tersebut sebagian besar adalah stimulus. Seiring berkembangnya daya pikir, lambat laun dominasi gerakan refleks ini semakin berkurang. Perkembangan ini didapat melalui pengalaman belajar merasakan dan mengenal obyek, sehingga pada akhir tahap ini anak dapat "membedakan". Ada 6 sub-tahapan, yaitu:

a. Sub-tahapan skema refleks, muncul saat lahir sampai usia enam minggu dan berhubungan terutama dengan refleks.

b. Sub-tahapan fase reaksi sirkular primer, dari usia enam minggu sampai empat bulan dan berhubungan terutama dengan munculnya kebiasaan-kebiasaan.

c. Sub-tahapan fase reaksi sirkular sekunder, muncul antara usia empat sampai sembilan bulan dan berhubungan terutama dengan koordinasi antara penglihatan dan pemaknaan.

d. Sub-tahapan koordinasi reaksi sirkular sekunder, muncul dari usia sembilan sampai duabelas bulan, saat berkembangnya kemampuan untuk melihat objek sebagai sesuatu yang permanen walau kelihatannya berbeda kalau dilihat dari sudut berbeda (permanensi objek). 
e. Sub-tahapan fase reaksi sirkular tersier, muncul dalam usia dua belas sampai delapan belas bulan dan berhubungan terutama dengan penemuan cara-cara baru untuk mencapai tujuan.

f. Sub-tahapan awal representasi simbolik, berhubungan terutama dengan tahapan awal kreativitas.

\section{Tahap Praoperasional}

Tahap ini merupakan tahapan kedua dari empat tahapan. Menurut Piaget, tahapan pra-operasional mengikuti tahapan sensorimotor dan muncul antara usia dua sampai enam tahun. Ciri dari tahapan ini adalah operasi mental yang jarang dan secara logika tidak memadai. Dalam tahapan ini, anak belajar menggunakan dan merepresentasikan objek dengan gambaran dan kata-kata. Keterampilan berbahasa anak mulai berkembang pada tahapan ini. Meski demikian, penalaran yang mereka gunakan masih bersifat intuitif bukan logis.

Pada tahap ini, anak masih bersifat egosentris. Mereka tidak bisa memahami tempatnya di dunia dan bagaimana banyak hal bisa berhubungan satu sama lain. Anak juga mengalami kesulitan untuk melihat sesuatu dari sudut pandang orang lain. Dalam tahap praoperasional, anak mampu mengklasifikasikan objek menggunakan satu ciri, seperti mengumpulkan semua benda kuning meskipun memiliki bentuk yang berbeda atau mengumpulkan semua benda bulat meskipun berbeda warna.

Meski di permulaan mereka masih egosentris, namun seiring pendewasaan, kemampuan untuk memahami perspektif orang lain semakin baik. Anak memiliki pikiran yang sangat imajinatif di saat ini dan menganggap setiap benda yang tidak hidup pun memiliki perasaan.

Tahap praoperasional dapat juga dikatakan sebagai tahap persiapan dalam pengorganisasian operasi konkret. Tahap ini dapat dibagi ke dalam tahap berpikir pra-logis dan tahap berpikir intuitif. 
Tahap berpikir pra-logis berada pada rata-rata usia sekitar 2 - 4 tahun. Pada tahap ini anak memiliki penalaran transduktif yaitu suatu penalaran yang bergerak dari khusus ke khusus. Tahap berpikir intuitif berada pada rata-rata usia sekitar 4 - 7 tahun. Pada tahap ini anak dapat menilai dan mempertimbangkan atas dasar persepsi pengalaman sendiri, oleh karena itu anak pada tahap ini bersifat egosentris.

Hal lain yaitu anak berpikir ireversibel, berpikir statis, dan concreteness. Berpikir ireversibel yaitu belum dapat berpikir kebalikan dari cara berpikir semula. Artinya anak tidak mampu memahami suatu transformasi atau perubahan-perubahan urutan dalam suatu peristiwa. Berpikir statis adalah salah satu ciri anak pada tahap preoperasional. Dengan kata lain anak pada tahap ini tidak menggunakan macam-macam operasi, melainkan hanya tertuju pada satu dimensi serta tidak memperhatikan gerakan-gerakan perubahan.

Concreteness adalah kemampuan berpikir anak masih berorientasi pada hal-hal yang konkret. Anak belum mampu memahami hal-hal yang abstrak atau yang direpresentasikan secara verbal. Pada akhir tahap ini merupakan saat transisi ke operasional konkret, disini mungkin saja terjadi penguasaan konservasi panjang, bilangan, dan kuantitas.

\section{Tahap Operasional Konkret}

Tahap ini merupakan tahapan ketiga dari empat tahapan. Anak berusia antara enam sampai duabelas tahun berada pada tahap ini. Ciri berupa penggunaan logika yang memadai.

Tahap ini berada pada saat anak-anak usia SD. Tahap ini merupakan permulaan berpikir rasional. Pada tahap operasional konkret anak mampu berpikir logis melalui obyek-obyek konkret, dan sulit memahami hal-hal yang hanya direpresentasikan secara verbal (Sund; Becker, Engelman \& Thomas; Bolton; Beard \& Hunt dalam La 
Maronta Galib, 1992:22). Peristiwa berpikir dan belajar anak pada tahap ini sebagian besar melalui pengalaman yang nyata (Carin \& Sund, 1989:29) yang berawal dari proses interaksi anak dengan obyek (benda) bukan dengan lambang, gagasan ataupun abstraksi.

Dapat dikatakan bahwa pada tahap ini anak-anak belum mampu melakukan proses berpikir yang abstrak. Anak juga belum mampu belajar dengan baik tentang proses sains yang abstrak (seperti tentang peristiwa fotosintesis), serta selalu mengalami kesulitan dalam memahami konsep yang abstrak, seperti mempelajari konsep gravitasi.

Meski demikian anak pada tahap ini memiliki operasi yang dapat dikembangkan yaitu operasi penjumlahan, pengurangan, perkalian, pembagian, klasifikasi, korespondensi, penempatan urutan. Anak juga menguasai pengukuran dan konservasi volume, berat dan luas.

Kemampuan konservasi artinya anak memahami bahwa kuantitas, panjang, atau jumlah benda-benda adalah tidak berhubungan dengan pengaturan atau tampilan dari objek atau benda-benda tersebut. Sebagai contoh, bila anak diberi cangkir yang seukuran dan isinya sama banyak, mereka akan tahu bila air dituangkan ke gelas lain yang ukurannya berbeda, air di gelas itu akan tetap sama banyak dengan isi cangkir lain.

Selain beberapa ciri yang telah disebutkan di atas, anak-anak tahap operasional konkret sudah memperlihatkan kemampuan berpikir kombinativitas (combinativity), reversibilitas (reversibility), asosiatif (assosiative), dan identitas (identity) (Ratna W. Dahar, 1989: 154; Woolfolk \& Nicolich, 1980: 58).

Kemampuan berpikir kombinativitas (combinativity) adalah kemampuan mengadakan berbagai kombinasi dari macam-macam hubungan. Contoh, anak dapat menyimpulkan bahwa $A$ lebih besar dari C, apabila A lebih besar dari B dan B lebih besar dari C. Atau A sama dengan $C$, karena $A$ sama dengan $B$ dan $B$ sama dengan $C$ (pemahaman transitif). 
Kemampuan berpikir reversibilitas (reversibility) adalah kemampuan berpikir atau melakukan operasi-operasi sebagai kebalikan dari cara berpikir semula. Anak mulai memahami bahwa jumlah atau benda-benda dapat diubah, kemudian kembali ke keadaan awal. Untuk itu, anak dapat dengan cepat menentukan bahwa 4+4 sama dengan 8, 8-4 akan sama dengan 4, jumlah sebelumnya. Operasi yang dapat dilakukan seperti operasi logis atau matematis yang dapat dihadapkan dengan operasi yang berlawanan. Contohnya, $9-5=4$, maka $4+5=9$. Reversibilitas ini merupakan sifat esensial dalam sistem kognisi, penguasaannya, penting untuk dapat memahami konsep-konsep sains dan matematika.

Kemampuan berpikir asosiatif (assosiative) adalah kemampuan untuk mencapai suatu jawaban dengan menggunakan beberapa cara yang menghubungkan unsur-unsur yang terdapat dalam suatu objek atau peristiwa. Kemampuan berpikir ini misalnya ditunjukkan oleh kemampuan menyimpulkan bahwa setiap orang memiliki orang tua; Tidak ada ikan yang hidup di darat, karena semua ikan yang ditemukan selalu bercirikan tempat hidupnya air.

Kemampuan berpikir identitas (identity) adalah kemampuan memahami sifat-sifat tertentu dari suatu objek yang tidak berubah bila tidak ditambah atau dikurangi. Dalam hal ini keadaan menjadi sama atau serupa dalam aspek-aspek tertentu meskipun telah dilakukan transformasi-transformasi. Kemampuan berpikir ini sangat berkaitan dengan kemampuan berpikir konservasi (ketetapan).

Mengacu pada teori di atas maka anak pada tahap operasional konkret tidak mudah dikelabui oleh perbedaan-perbedaan persepsi seperti yang terjadi pada anak preoperasional. Oleh karena itu anak pada tahap operasional konkret sudah memiliki pemahaman konservasi.

Artinya anak pada tahap operasional konkret sudah dapat melakukan perubahan-perubahan suatu "obyek" secara fisik, dan menyatakan bahwa perubahan bentuk, posisi, dan sebagainya tidak 
akan merubah jumlah proporsi obyek tersebut (Moh. Amien, 1987: 61; Woolfolk \& Nicolich, 1980: 56). Namun demikian hasil penelitian di USA membuktikan bahwa sejumlah besar sekolah menengah atas masih mempunyai kesulitan dalam memahami konservasi (Moh. Amien, 1987: 62).

Anak pada tahap operasional konkret juga sudah memiliki kemampuan untuk memberi nama dan mengidentifikasi serangkaian benda menurut tampilannya, ukurannya, atau karakteristik lain, termasuk gagasan bahwa serangkaian benda-benda dapat menyertakan benda lainnya ke dalam rangkaian tersebut. Anak tidak lagi memiliki keterbatasan logika berupa animisme (anggapan bahwa semua benda hidup dan berperasaan).

Selain itu, anak mulai mempertimbangkan beberapa aspek dari suatu permasalahan untuk bisa memecahkannya. Sebagai contoh, anak tidak akan lagi menganggap bahwa cangkir yang pendek tapi lebar memiliki isi lebih sedikit dibanding cangkir yang tinggi tapi ramping.

Berbeda dengan tahap praoperasional, anak yang berada pada tahap operasional konkret telah memiliki kemampuan untuk melihat sesuatu dari sudut pandang orang lain (bahkan saat orang tersebut berpikir dengan cara yang salah). Sebagai contoh, tunjukkan komik yang memperlihatkan Siti menyimpan boneka di dalam kotak, lalu meninggalkan ruangan, kemudian Ujang memindahkan boneka itu ke dalam laci, setelah itu baru Siti kembali ke ruangan. Anak dalam tahap operasi konkret akan mengatakan bahwa Siti akan tetap menganggap boneka itu ada di dalam kotak walau anak itu tahu bahwa boneka itu sudah dipindahkan ke dalam laci oleh Ujang.

4. Tahap Operasional Formal

Tahap operasional formal adalah tahapan terakhir perkembangan kognitif dalam teori Piaget. Tahap ini mulai dialami 
anak dalam usia sebelas tahun (saat pubertas) dan terus berlanjut sampai dewasa. Karakteristik tahap ini adalah diperolehnya kemampuan untuk berpikir secara abstrak, menalar secara logis, dan menarik kesimpulan dari informasi yang tersedia. Dalam tahapan ini, seseorang dapat memahami hal-hal seperti cinta, bukti logis, dan nilai. la tidak melihat segala sesuatu hanya dalam bentuk hitam dan putih, namun ada "gradasi abu-abu" di antaranya.

Dilihat dari faktor biologis, tahapan ini muncul saat pubertas (saat terjadi berbagai perubahan besar lainnya), menandai masuknya ke dunia dewasa secara fisiologis, kognitif, penalaran moral, perkembangan psikoseksual, dan perkembangan sosial. Beberapa orang tidak sepenuhnya mencapai perkembangan sampai tahap ini, sehingga ia tidak mempunyai keterampilan berpikir sebagai seorang dewasa dan tetap menggunakan penalaran dari tahap operasional konkret.

Tahap operasional formal disebut juga tahap akhir dari perkembangan kognitif (intelektual) menurut Piaget, sebab setelah itu tidak terjadi lagi peningkatan kualitas intelektual. Berbeda dengan anak yang berada pada tahap sebelumnya, anak operasional formal mampu melakukan penalaran dengan simbol-simbol, ide-ide, abstraksi, dan generalisasi-generalisasi. Artinya anak-anak operasional formal sudah bisa menggunakan operasi logisnya untuk menyelesaikan masalah-masalah yang bersifat verbal, rumit, dan kompleks.

Disini logika sudah menjadi alat berpikir anak ini sehingga ia mampu melakukan operasi terhadap operasi. Artinya anak bisa melakukan operasi dengan tidak mengacu pada obyek, tetapi pada sumber yang ditangkap dari relasi yang terkandung dalam informasi (operasi-operasi) yang diberikan dan menggunakannya untuk menemukan hubungan.

Dengan memperhatikan kemampuan-kemampuan tersebut, kita dapat membedakan anak yang berada pada tahap operasional 
formal dengan anak yang berada pada tahap sebelumnya. Misalnya untuk mengetahui tahap perkembangan anak yang dilakukan dengan memberi tugas konservasi; reaksi dari anak tahap operasional konkret berbeda dengan anak tahap operasional formal. Boleh jadi bagi anak tahap operasional formal tidak menanggapinya dengan serius karena baginya masalah tersebut sudah jelas.

Keempat tahapan kognitif menurut Piaget ini memiliki ciri-ciri sebagai berikut:

a. Walau tahapan-tahapan itu bisa dicapai dalam usia bervariasi tetapi urutannya selalu sama. Tidak ada ada tahapan yang diloncati dan tidak ada urutan yang mundur.

b. Universal (tidak terkait budaya)

c. Bisa digeneralisasi: representasi dan logika dari operasi yang ada dalam diri seseorang berlaku juga pada semua konsep dan isi pengetahuan

d. Tahapan-tahapan tersebut berupa keseluruhan yang terorganisasi secara logis

e. Urutan tahapan bersifat hirarkis (setiap tahapan mencakup elemen-elemen dari tahapan sebelumnya, tapi lebih terdiferensiasi dan terintegrasi)

f. Tahapan merepresentasikan perbedaan secara kualitatif dalam model berpikir, bukan hanya perbedaan kuantitatif

Perubahan dari tahap yang satu ke tahap lain kecepatannya tidak pasti (berbeda) untuk masing-masing individu. Oleh karena itu bila anak yang berada pada tahap tertentu dapat dengan cepat berubah ke tahap berikutnya, maka perubahan yang terjadi boleh jadi disebabkan oleh adanya perbedaan latar belakang, kemampuan, ketangkasan, dan upaya anak. Penentuan rentang usia pun, tidak berlaku pasti, tetapi merupakan rata-rata. Meskipun demikian urutan tahap dalam melampaui satu tahap ke tahap berikutnya selalu sama, 
tidak ada individu yang loncat tahap. Walaupun demikian tidak menutup kemungkinan adanya individu yang tidak sampai ke tahap operasional formal.

\section{B. TAHAPAN MENURUT BRUNNER}

Bruner berpendapat bahwa pemahaman terhadap konsep suatu materi menjadikan sebuah materi mudah dipahami secara lebih komprehensif (Pitajeng, 2016). juga lebih mudah mengingat materi jika yang ia pelajari mempunyai pola terstruktur. Dengan memahami konsep dan struktur akan mempermudah terjadinya transfer.

Menurut Bruner, pertumbuhan intelektual secara langsung berhubungan dengan kemampuan menjawab stimulus. Pertumbuhan intelektual seorang anak juga tergantung pada kemampuan memproses informasi internal dan menyimpan sistem untuk menghadirkan dunia. Mereka membutuhkan sistem simbol (seperti bahasa), untuk meramalkan kemungkinan, dan menghipotesa.

Perkembangan intelektual meliputi kemampuan anak dalam menggambarkan kegiatan lalu dan yang akan datang. Anak-anak memerlukan interaksi sistematis dengan orang dewasa untuk mencapai perkembangan kognitif. Anak-anak memerlukan bahasa untuk berkomunikasi dengan orang lain, bertanya, menghubungkan yang baru dengan yang lama.

Berdasarkan hasil studinya, Burner mengidentifikasi tiga tahapan perkembangan yaitu enaiktif, ikonik, dan simbolik. Meskipun ketiganya memiliki karakteristik perkembangan yang sama dengan Piaget, tetapi apa yang dinyatakan Burner tidak menekankan pada hierarki alamiah. Menurut Bruner perkembangan kognitif seseorang terjadi tiga tahap yang ditentukan oleh caranya melihat lingkungan, yaitu:

1. Tahap enaktif, seseorang melakukan aktivitas-aktivitas dalam upayanya untuk memahami lingkungan sekitarnya. Tahapan 
pertama ini umumnya dialami anak-anak, sebagian besar didominasi oleh belajar sambil bekerja. Anak-anak menggunakan/melakukan sesuatu dengan objek secara langsung, -misalnya: memegang, menggigit, bergerak, menggosok, menyentuh dan memberikan kesempatan mereka untuk memahami lingkungannya.

2. Tahap ikonik, seseorang memahami objek-objek atau dunianya melalui gambar-gambar dan visualisasi verbal. Dalam memahami dunia sekitar anak belajar melalui bentuk perumpamaan (tampil) dan perbandingan (komparasi). Tahapan ini meliputi penggunaan imajinasi, bukan bahasa. Anak-anak memutuskan kegiatan berdasarkan pada kesan-kesan sensor. Tahapan ini merujuk pada jenis-jenis belajar yang meliputi kemampuan untuk mengenal secara langsung sesuatu tanpa mampu memberikan sejumlah konsep.

Pada tahap ini, kegiatan mulai menyangkut mental yang merupakan gambaran dari objek-objek konkret. Mereka tidak memanipulasi langsung seperti pada tahap enaktif, tetapi sudah mampu memanipulasi dengan menggunakan gambaran dari objek yang dimaksud.

3. Tahap simbolik, seeorang telah mampu memiliki ide-ide atau gagasan-gagasan abstrak yang sangat dipengaruhi oleh kemampuannya dalam berbahasa dan logika. Komunikasi banyak menggunakan bahasa simbol. Semakin matang seseorang dalam proses berpikirnya, semakin dominan sistem simbolnya. Tahap ini merupakan tahap memanipulasi simbol-simbol secara langsung dan tidak lagi ada kaitannya dengan objek-objek.

Tahap ini sekaligus merupakan tahapan terakhir dimana anak-anak memperoleh pemahaman melalui penggunaan sistem simbol. Jenis-jenis system simbol tersedia pada anak-anak, termasuk bahasa, logika, dan matematika. 
Sistem-sistem membolehkan anak-anak untuk menyusun gagasannya dan menyimpannya agar dapat diambil kembali saat ia membutuhkannya.

\section{TAHAPAN MENURUT AHLI LAINNYA}

Selain Piaget dan Bruner, ada pula tahap perkembangan menurut Vygotsky. Teori Vygotsky fokus pada aspek sosial yang menyatakan bahwa kecenderungan satu kebudayaan menentukan stimulus yang terjadi. Anak-anak menginternalisasikan satu aspek tertentu untuk mempertahankan dedikasinya pada kebudayaan yang spesifik.

Vygotsky menunjukkan empat tahapan perkembangan, yaitu:

1. Berpikir non-verbal dan berbicara konseptual. Tahapan ini ada pada usia dua tahun pertama; menunjukkan tidak ada hubungan antara berpikir dan berbicara.

2. Memulai menyatukan antara berpikir dan berbicara. Tahapan ini kira-kira usia 2 tahun; anak-anak mulai menghubungkan apa yang dia pikirkan dengan apa yang dia katakana. Benda-benda biasanya diberi nama dan diceritakannya pada orang lain.

3. Berbicara egosentrik. Pembicaraan anak-anak dimulai pada mengarahkan berpikir dan berprilaku. Anak-anak pada tahap ini mengumumkan apa yang akan mereka lakukan sebelum melakukannya. Anak-anak pada tahap ini berbicara dengan orang lain tentang apa yang sedang mereka lakukan.

4. Berbicara egosentrik menjadi rahasia. Pembicaraan egosentrik rahasia secara bertahap berubah menjadi pembicaraan rahasia. Anak-anak mulai menggunakan pembicaraan rahasia dan singkatan tentang kegiatannya.

Sumbangan penting teori Vygotsky adalah penekanan pada hakekatnya pembelajaran sosiokultural. Inti teori Vygotsky adalah 
menekankan interaksi antara aspek "internal" dan "eksternal" dari pebelajar dan penekanannya pada lingkungan sosial pebelajar. Menurut teori Vygotsky, fungsi kognitif berasal dari interaksi sosial masing - masing individu dalam konsep budaya.

Vygotsky juga yakin bahwa pembelajaran terjadi saat bekerja menangani tugas - tugas yang belum dipelajari namun tugas- tugas itu berada dalam "zone of proximal development" mereka. Zone of proximal development adalah jarak antara tingkat perkembangan sesungguhnya yang ditunjukkan dalam kemampuan pemecahan masalah secara mandiri dan tingkat kemampuan perkembangan potensial yang ditunjukkan dalam kemampuan pemecahan masalah di bawah bimbingan orang dewasa atau teman sebaya yang lebih mampu.

Teori Vygotsky yang lain adalah "scaffolding". Scaffolding adalah memberikan kepada seseorang anak sejumlah besar bantuan selama tahap-tahap awal pembelajaran dan kemudian mengurangi bantuan tersebut dan memberikan kesempatan kepada anak tersebut mengambil alih tanggung jawab yang semakin besar segera setelah ia mampu mengerjakan sendiri.

Bantuan yang diberikan guru dapat berupa petunjuk, peringatan, dorongan menguraikan masalah ke dalam bentuk lain yang memungkinkan dapat mandiri.

\section{BAB 4}

METODE DAN MODEL PEMBELAJARAN IPS SD 
Bab ini berisi tentang berbagai metode dan model pembelajaran IPS SD. Penulisan bab ini bertujuan agar pembaca mampu:

1. Menjelaskan definisi metode pembelajaran

2. Menjelaskan definisi model pembelajaran

3. Menganalisis keterkaitan metode dan model pembelajaran

4. Memberi contoh metode-metode dan model-model pembelajaran IPS, khususnya untuk SD kelas awal

5. Menguraikan kelebihan dan kelemahan masing-masing metode dan model pembelajaran

6. Memberi alasan perlunya variasi metode dan model pembelajaran pendidikan IPS SD

7. Mengimplementasikan beragam metode dan model pembelajaran dalam pendidikan IPS SD kelas awal

\section{A. METODE PEMBELAJARAN}

Ada beberapa istilah dalam pembelajaran yang memiliki kemiripan, sehingga seringkali dianggap sebagai hal yang sama. 
Seringkali orang merasa bingung untuk membedakannya. Istilah-istilah tersebut adalah: (1) pendekatan pembelajaran, (2) strategi pembelajaran, (3) metode pembelajaran, (4) teknik pembelajaran, (5) taktik pembelajaran, dan (6) model pembelajaran. Berikut ini pemaparan pengertian istilah - istilah tersebut agar dapat memberikan kejelasaan tentang penggunaan istilah tersebut.

Pendekatan pembelajaran dapat diartikan sebagai titik tolak atau sudut pandang kita terhadap proses pembelajaran, yang merujuk pada pandangan tentang terjadinya suatu proses yang sifatnya masih sangat umum, di dalamnya mewadahi, menginsiprasi, menguatkan, dan melatari metode pembelajaran dengan cakupan teoretis tertentu. Dilihat dari pendekatannya, pembelajaran terdapat dua jenis pendekatan, yaitu: (1) pendekatan pembelajaran yang berorientasi atau berpusat pada (student centered approach) dan (2) pendekatan pembelajaran yang berorientasi atau berpusat pada guru (teacher centered approach).

Dari pendekatan pembelajaran yang telah ditetapkan selanjutnya diturunkan ke dalam Strategi Pembelajaran. Newman dan Logan (Abin Syamsuddin Makmun, 2003) mengemukakan empat unsur strategi dari setiap usaha, yaitu:

1. Mengidentifikasi dan menetapkan spesifikasi dan kualifikasi hasil dan sasaran/target yang harus dicapai, dengan mempertimbangkan aspirasi dan selera masyarakat yang memerlukannya.

2. Mempertimbangkan dan memilih jalan pendekatan utama (basic way) yang paling efektif untuk mencapai sasaran.

3. Mempertimbangkan dan menetapkan langkah-langkah (steps) yang akan dtempuh sejak titik awal sampai dengan sasaran.

4. Mempertimbangkan dan menetapkan tolak ukur/kriteria dan patokan ukuran/standard untuk mengukur dan menilai taraf keberhasilan usaha. 
Jika kita terapkan dalam konteks pembelajaran, keempat unsur tersebut adalah:

1. Menetapkan spesifikasi dan kualifikasi tujuan pembelajaran yakni perubahan profil perilaku dan pribadi siswa.

2. Mempertimbangkan dan memilih sistem pendekatan pembelajaran yang dipandang paling efektif.

3. Mempertimbangkan dan menetapkan langkah-langkah atau prosedur, metode dan teknik pembelajaran.

4. Menetapkan norma-norma dan batas minimum ukuran keberhasilan atau kriteria dan ukuran baku keberhasilan.

Sementara itu, Kemp (Wina Senjaya, 2008) mengemukakan bahwa strategi pembelajaran adalah suatu kegiatan pembelajaran yang harus dikerjakan guru dan agar tujuan pembelajaran dapat dicapai secara efektif dan efisien. Selanjutnya, dengan mengutip pemikiran J. R David, Wina Senjaya (2008) menyebutkan bahwa dalam strategi pembelajaran terkandung makna perencanaan. Artinya, bahwa strategi pada dasarnya masih bersifat konseptual tentang keputusan-keputusan yang akan diambil dalam suatu pelaksanaan pembelajaran.

Dilihat dari strateginya, pembelajaran dapat dikelompokkan ke dalam dua bagian pula, yaitu: (1) exposition-discovery learning dan (2) group-individual learning (Rowntree dalam Wina Senjaya, 2008). Ditinjau dari cara penyajian dan cara pengolahannya, strategi pembelajaran dapat dibedakan antara strategi pembelajaran induktif dan strategi pembelajaran deduktif. Strategi pembelajaran sifatnya masih konseptual dan untuk mengimplementasikannya digunakan berbagai metode pembelajaran tertentu. Dengan kata lain, strategi merupakan "a plan of operation achieving something" sedangkan metode adalah "a way in achieving something".

Metode pembelajaran di sini dapat diartikan sebagai cara yang digunakan untuk mengimplementasikan rencana yang sudah disusun 
dalam bentuk kegiatan nyata dan praktis untuk mencapai tujuan pembelajaran. Dapat disimpulkan bahwa metode pembelajaran merupakan cara guru memfasilitasi nya beklajar agar tercapai tujuan pembelajaran yang diharapkan.

Terdapat beragam metode pembelajaran yang dapat digunakan untuk mengimplementasikan strategi pembelajaran, diantaranya: (1) ceramah; (2) demonstrasi; (3) diskusi; (4) simulasi; (5) praktikum; (6) tanya jawab; (7) brainstorming; (8) debat, (9) simposium, dan sebagainya. Setiap metode mempunya kelebihan dan kelemahan masing-masing. Tidak ada metode pembelajaran yang paling baik atau paling cocok digunakan untuk semua materi.

Saat memilih metode pembelajaran, hendaknya guru perlu memperhatikan hal-hal berikut ini:

1. Tujuan pembelajaran

Setiap perjalanan tentu mempunyai tujuan, demikian halnya dengan pembelajaran. Tujuan pembelajaran akan memberikan arah yang tepat sehingga guru memiliki gambaran untuk menentukan metode yang akan digunakan. Metode yang dipilih oleh guru hendaknya dipertimbangkan kesesuaiannya dengan tujuan pembelajaran. Keberhasilan suatu pembelajaran salah satunya dari tercapainya tujuan pembelajaran, dan tujuan pembelajaran dapat tercapai jika guru mampu memilih metode yang sesuai untuk mencapai tujuan tersebut.

2. Karakteristik Siswa

Pemilihan metode juga harus memperhatikan karakteristik siswa. Guru sebagai orangtua di sekolah tentu memahami karakteristik dan kemampuan nya. Sebagai orang terdekat siswa, saat memilih metode guru harus mempertimbangkan kemampuan siswa. Apakah metode yang dipilih memudahkan siswa dalam belajar, atau malah menghambat siswa mencapai tujuan pembelajaran karena keterbatasan/perbedaan kemampuan siswa. 
3. Kemampuan guru

Selain kemampuan siswa, yang juga harus dipertimbangkan dalam memilih metode adalah kemampuan guru itu sendiri. Guru sebagai seorang individu yang profesional tentu mengetahui kapasitas dirinya. Meski demikian, hal ini tidak boleh dijadikan alasan untuk terus menggunakan metode yang sama dalam mencapai beragam tujuan yang berbeda. Jika guru merasa kurang mampu menggunakan suatu metode tertentu, guru dapat mencari alternatif metode lain. Tetapi, guru tetap harus mempelajari metode tersebut, sehingga jika suatu ketika metode tersebut cocok digunakan untuk mencapai tujuan pembelajaran yang lain, guru sudah menguasai metode tersebut.

4. Banyaknya siswa yang belajar

Banyaknya siswa yang belajar dalam satu rombongan belajar tentu tidak sama antar kelas, antar jenjang, maupun antar sekolah. Ada rombel yang hanya diisi kurang dari 10 siswa, ada yang antara 10-20 siswa, ada pula yang isinya lebih dari 20 siswa bahkan 30 lebih. Misalnya, metode ceramah dapat digunakan untuk siswa yang jumlahnya banyak.

5. Fasilitas yang dimiliki

Penggunaan metode yang bervariasi semakin bagus jika diterapkan oleh guru. Tetapi, pemilihan metode tersebut juga harus mempertimbangkan fasilitas/sarana prasarana yang dimiliki. Misalnya metode praktikum yang mestinya dilakukan secara individu, tetapi karena keterbatasan fasilitas, maka dilakukan dengan cara berkelompok.

6. Situasi dan kondisi

Setiap metode tidak hanya memiliki kelebiha, tetapi juga kelemahan. Untuk meminimalisir kelemahan tersebut, maka guru hendaknya mempertimbangkan situasi dan kondisi sebelum memilih metode yang akan digunakan. Sebagai contoh, 
metode ceramah sangat efektif dan efisien jika digunakan untuk mengajar yang jumlahnya banyak. Tetapi, metode ini menjadi tidak efektif saat guru menggunakannya siang hari tanpa bantuan media apapun, ketika kondisi sudah lelah, apalagi jika materi yang dipelajari cukup rumit dan abstrak.

Metode seperti yang sudah disebutkan sebelumnya, merupakan cara kita untuk mencapai sesuatu. Jika strategi merupakan rencana yang disusun untuk mencapai sesuatu, maka metode berfokus kepada cara apa saja yang dilakukan untuk mewujudkannya. Contoh pemanfaatan metode dalam pembelajaran sebagai berikut.

Siswa kelas 3 akan belajar mengenai denah dan arah mata angin. Guru mengajak menyanyi lagu tentang arah mata angin sambil mendemonstrasikan gerakan badan dan tangan yang menunjukkan arah mata angin tertentu. Dari demonstrasi guru, siswa menirukan gerakan tersebut seraya belajar berbagai arah mata angin melalui lagu yang dinyanyikan.

Setelah belajar melalui demonstrasi, sesuai arahan guru, maka siswa bergabung dengan kelompok yang telah ditentukan. Setiap kelompok ada yang mengukur ruang kelas 1, kelas 2, dan lain-lain. Anak-anak yang telah selesai mengukur diminta kembali lagi ke dalam kelas. Dengan bimbingan guru, mereka menggambar denah sekolah.

Setelah menggambar denah, guru juga membagi sub-topik untuk didiskusikan masing-masing kelompok dan tanya jawab. Hal ini menunjukkan bahwa untuk mengajarkan suatu materi tidak cukup hanya menggunakan satu metode, melainkan dibutuhkan beberapa metode. Berikut ini akan dipaparkan beberapa metode mengajar bersama kelebihan dan kelemahannya.

1. Metode Ceramah 
Ceramah merupakan pidato yang disampaikan seseorang sebagai pembicara di depan sekelompok pengunjung, dalam hal ini guru di depan. Guru yang menggunakan metode ceramah biasanya memberikan materi/penjelasan kepada secara lisan dan menyimak dengan seksama.

Metode ini sangat baik digunakan jika jumlah nya banyak. Selain itu, metode ini juga sangat baik digunakan untuk menjelaskan materi yang cukup banyak dengan waktu yang terbatas. Selain itu, metode ceramah juga dapat digunakan untuk menambah bahan yang tekah dibaca/dipelajari .

Metode ini menjadi kurang baik jika kurangnya penguasaan materi/bahan pelajaran oleh guru. Guru yang kurang memiliki keterampilan berbicara yang baik, juga mengakibatkan kebosanan pada saat mengikuti pembelajaran dengan metode ini. Oleh sebab itu, guru hendaknya mampu mengemas materi dan menyajikannya secara lisan dengan cara yang menarik dan interaktif sehingga tetap antusias mengikuti pembelajaran.

Kelebihan Metode Ceramah:

- Guru mudah menguasai situasi dan kondisi kelas.

- Guru mudah menerangkan bahan-bahan pelajaran berkuantitas banyak.

- Dapat diikuti oleh siswa dalam jumlah yang besar.

- Tergolong mudah dalam pelaksanaan.

Kelemahan Metode Ceramah:

- Menjadikan siswa menjadi pasif.

- Mengandung unsur paksaan kepada siswa.

- Mengandung daya kritis kepada siswa.

- Siswa yang lebih tanggap dari segi visual akan menjadi rugi dan siswa yang lebih tanggap segi auditifnya dapat lebih besar menerimanya.

- Sulit mengendalikan sejauhmana perkembangan belajar siswa. 
- Kegiatan pengajaran menjadi verbalisme (pengertian kata-kata).

- Membosankan bila terlalu lama.

2. Metode Diskusi Kelompok

Metode diskusi ialah cara mengajar yang sangat erat kaitannya dengan pemecahan suatu masalah. Metode ini umum dikenal dengan diskusi kelompok dan resitasi bersama (socialized recitation).

Tujuan dari pelaksanaan dari metode ini ialah untuk:

- Mendorong siswa berpikir secara kritis.

- Siswa didorong untuk mampu mengutarakan pendapatnya secara bebas.

- Mendorong siswa untuk menyumbangkan idenya untuk memecahkan masalah bersama.

- Mampu membuat siswa untuk mengambil sebuah atau beberapa alternatif jawaban untuk memecahkan masalaah berdasar pertimbangan tertentu.

Kelebihan Metode Diskusi:

- Memperluas wawasan siswa.

- Mengembangkan sikap saling menghargai pendapat orang lain.

- Membiasakan siswa musyawarah mufakat dalam menyelesaikan masalah.

- Siswa tersadar bahwa masalah mampu dipecahkan dengan banyak cara.

- Membuat siswa sadar bahwa dengan saling berdiskusi dan mengemukakan pendapat secara konstruktif mampu mendapatkan keputusan yang terbaik.

- Membiasakan siswa untuk mendengarkan pendapat atau ide orang lain walaupun berbeda

- Membiasakan siswa bersikap toleransi. 
Kelemahan Metode Diskusi:

- Tak cocok untuk digunakan dalam skala besar.

- Informasi yang didapat siswa terbatas.

- Hanya dapat dikuasai oleh siswa yang suka berbicara.

- Memerlukan pendekatan yang lebih formal.

- Pembicaraan terkadang menyimpang sehingga memerlukan waktu yang panjang.

3. Metode Tanya Jawab

Tanya jawab disajikan dalam bentuk pertanyaan yang harus dijawab, utamanya dari guru kepada siswa, tetapi bisa juga dari siswa kepada guru. Metode ini banyak digunakan dalam proses pendidikan. Metode ini dapat dipakai ketika guru ingin menanyakan kembali apa yang diajarkan kepada siswa. Guru juga dapat melakukan tanya jawab untuk memimpin pengamatan dan pemikiran siswa.

Kelebihan Metode Tanya Jawab:

- Siswa lebih aktif karena tidak hanya mendengarkan.

- Memberi siswa kesempatan untuk bertanya sehingga guru tahu apa yang belum dimengerti siswanya.

- Guru mengetahui pemahaman siswanya terhadap materi yang telah dipelajari.

- Pertanyaan dapat memusatkan perhatian siswa.

- Mengembangkan daya pikir dan daya ingat siswa.

- Melatih keberanian dan keterampilan siswa dalam menjawab dan mengemukakan pendapat.

Kelemahan Metode Tanya Jawab:

- Pembicaraan yang dilakukan kadang menyimpang dari pokok pembicaraan/yang semestinya dibicarakan.

- Membutuhkan waktu yang cukup lama. 
- Siswa merasa takut menjawab, takut salah, malu jika salah dll, terutama jika guru kurang mendorong siswa untuk berani.

- Tidak mudah membuat pertanyaan yang sesuai dengan tingkat berpikir siswa namun tetap mudah dipahami siswa.

- Kurangnya waktu jika jumlah siswanya banyak sehingga tidak bisa memberikan pertanyaan kepada setiap siswa.

4. Metode Demonstrasi

Yaitu metode mengajar dengan cara memperagakan sebuah barang, peristiwa, aturan, dan urutan melakukan suatu aktivitas, baik secara langsung maupun tak langsung melalui penggunaan sebuah media pengajaran yang relevan dengan materi atau pokok pembahasan yang sedang disajikan.

Manfaat psikologis pedagogis dari pelaksaaan metode demonstrasi ini ialah:

- Perhatian siswa bisa lebih dipusatkan .

- Proses belajar siswa lebih terarah pada materi yang sedang dipelajari saja.

- Pengalaman dan kesan sebagai hasil pembelajaran lebih melekat dalam diri siswa.

Kelebihan Metode Demonstrasi:

- Siswa terbantu dalam memahami secara jelas suatu proses atau kerja sebuah benda.

- Mudah dalam bermacam-macam jenis penjelasan.

- Kesalahan yang terjadi dari hasil ceramah bisa diperbaiki melalui pengamatan dan contoh nyata dengan menghadirkan objek sebenarnya.

- Dapat membuat pengajaran menjadi lebih konkret dan jelas sehingga menghindari verbalisme 
- Siswa dirangsang untuk aktif melakuan pengamatan, menyesuaikan antara yang dipelajari dengan kenyataan, kemudian mencoba melakukannya sendiri

Kelemahan Metode Demonstrasi:

- Siswa kadang sulit untuk melihat secara jelas benda yang diperagakan.

- Tak semua benda dapat didemonstrasikan.

- Materi akan sulit untuk dipahami apabila guru kurang menguasai apa yang diperagakan.

- Memerlukan keterampilan guru secara khusus, jika tidak maka pelaksanaannya menjadi kurang efektif.

5. Metode resitasi

Resitasi dapat diartikan sebagai hafalan. Metode mengajar resitasi merupakan cara mengajar dimana siswa diharuskan membuat suatu resume dengan menggunakan kalimat sendiri.

Kelebihan Metode Resitasi:

- Pengetahuan yang diperoleh siswa dapat diingat lebih lama karena diperoleh dari hasil belajar mandiri.

- Siswa memiliki kesempatan untuk memupuk perkembangan dan menumbuhkan keberanian dalam mengambil inisiatif, mandiri, dan bertanggung jawab.

Kelemahan Metode Resitasi:

- Siswa kemungkinan bisa melakukan hal curang dengan hanya meniru hasil resume dari temannya, karena tak perlu susah payah.

- Tugas bisa saja dilakukan oleh orang lain disebabkan kurangnya pengawasan.

- Sulit memberikan tugas yang bersifat pemenuhan individual.

6. Metode Karyawisata 
Metode karyawisata merupakan suatu kegiatan belajar mengajar dimana siswa dibawa ke suatu objek di luar kelas untuk mengkaji atau mempelajari suatu masalah yang berhubungan dengan materi pelajaran atau dengan kata lain karyawisata merupakan suatu upaya mendekatkan atau membawa diri siswa kepada kehidupan nyata yang menjadi sumber belajar bagi para siswa.

Tujuan metode karyawisata adalah:

- Agar siswa dapat membandingkan apa yang mereka pelajari didalam kelas secara teoritis dengan keadaan nyata dilapangan, atau membandingkan antar keadaan nyata dengan praktek penggunaannya.

- Untuk menghilangkan kejenuhan siswa dalam belajar

- Untuk dijadikan ajang rekreasi bagi siswa sambil belajar.

Kelebihan Metode Karyawisata:

- Siswa memperoleh pengalaman langsung dari lapangan

- Dapat meningkatkan minat dan perhatian siswa dalam mempelajari sesuatu

- Dapat memperkaya dan menyempurnakan pengetahuan yang diperoleh siswa di dalam kelas

Kelemahan Metode Karyawisata

- Memerlukan persiapan yang relatif lama dan cukup matang

- Memerlukan sarana dan biaya yang relatif tinggi

- Bila persiapan kurang matang dapat mengaburkan tujuan

- Memiliki resiko yang cukup tinggi.

7. Metode Simulasi

Simulasi merupakan format interaksi belajar mengajar dalam pengajaran IPS yang didalamnya menampakan adanya prilaku pura-pura(simulasi) dari orang yang terlibat dalam proses pembelajaran atau suatu peniruan situasi tertentu, sehingga siswa dapat memahami konsep, prinsip-prinsip keterampilan, 
nilai dan sikap dari sesuatu dari yang sedang disimulasikan. Simulasi dapat berupa bermain peran maupun sosiodrama.

Tujuan penggunaan metode simulasi yaitu:

- Untuk mendorong partisipasi dan pengembangan sikap siswa.

- Mengembangkan interaksi dan komunikasi dalam proses pembelajaran.

- Dapat menimbulkan interaksi yang sehat dan hangat antar siswa.

- Memperkenalkan dan melatih peran kepemimpinan pada diri siswa.

- Memanfaatkan bakat dan kemampuan siswa sebagai sumber belajar.

Kelebihan Metode Simulasi:

- Dapat menciptakan kesenangan dan kegembiraan pada diri siswa dalam proses pembelajaran

- Dapat mengurangi keabstrakan pada diri siswa dalam proses pembelajaran

- Dapat memberikan pengarahan dan petunjuk sederhana dalam proses pembelajaran

- Dapat melatih siswa berpikir kritis

Kelemahan Metode Simulasi:

- Memerlkan waktu yang relatif lama dan biaya yang relatif mahal

- Memerlukan sistem pengelompokan siswa yang cukup luwes dan kompleks sesuai dengan peran yang akan dimainkannya

- Banyak menuntut imajinasi dan imfropisasi guru dan siswa dalam pelaksanaannya

- Sulit bagi siswa berperan sesuai dengan peran/tokoh yang dimainkannya

8. Metode Kerja Kelompok 
Metode kerja kelompok merupakan format belajar mengajar yang menitikberatkan kepada interaksi antara anggota yang satu dengan anggota yang lain dalam suatu kelompok, guna menyelesaikan tugas secara bersama-sama.

Tujuan penggunaan metode kerja kelompok adalah:

- Memupuk kemampuan dan kemauan bekerja sama bagi siswa

- Untuk meningkatkan keterlibatan sosio-emosional para siswa

- Untuk meningkatkan perhatian siswa pada pbm.

Jenis-jenis pengelompokan terdiri dari:

- Pengelompokan berdasarkan ketersediaan fasilitas belajar

- Pengelompokan berdasarkan perbedaan individu (bakat, minat, perhatian dan kemampuan)

- Pengelompokan berdasarkan pembagian pekerjaan

Metode kerja kelompok dapat digunakan untuk mengatasi kekurangan alat dan sumber belajar. Siswa dapat dikelompokkan sesuai dengan banyaknya alat/sumber belajar yang tersedia. Selain itu, metode kerja kelompok juga dapat digunakan untuk mengatasi perbedaan kemampuan belajar siswa, minat belajar siswa yang beragam, serta tugas pekerjaan yang sangat banyak/luas.

Kelebihan Metode Kerja Kelompok:

- Dapat memupuk rasa kerja sama

- Tugas yang luas dapat diselesaikan dengan cepat

- Timbul persaingan yang sehat

Kelemahan Metode Kerja Kelompok:

- Adanya siswa yang ingin terlihat menonjol dan ada pula siswa yang bergantung pada siswa yang lain

- Adanya dominasi seseorang dan siswa yang kurang cakap dapat menghambat kelancaran tugas

\section{B. MODEL PEMBELAJARAN}


Istarani (2012) menyebutkan bahwa model pembelajaran adalah seluruh rangkaian penyajian materi ajar yang meliputi segala aspek sebelum sedang dan sesudah pembelajaran yang dilakukan guru serta segala fasilitas yang terkait yang digunakan secara langsung atau tidak langsung dalam proses belajar mengajar. Dapat dikatakan bahwa model pembelajaran merupakan sebuah pola yang digunakan oleh seorang guru sebagai pedoman dalam proses pembelajaran. Beberapa model pembelajaran yang dapat digunakan untuk pembelajaran IPS yaitu berikut ini.

\section{Group Investigation}

Group Investigation merupakan model pembelajaran kooperatif yang melibatkan kelompok kecil dimana siswa bekerja menggunakan inquiri kooperatif, perencanaan, proyek, diskusi kelompok, dan kemudian mempresentasikan penemuan mereka kepada kelas. Model Group Investigation memiliki 3 konsep utama, yaitu: (1) penelitian (inquiry) yaitu proses dimana siswa dirangsang dengan menghidupkan pada suatu masalah. Siswa merasa dirinya perlu memberikan reaksi terhadap masalah yang dianggap perlu untuk diselesaikan. Masalah ini didapat dari siswa sendiri atau diberikan oleh guru; (2) pengetahuan yaitu pengalaman yang tidak dibawa sejak lahir namun diperoleh siswa melalui pengalaman baik secara langsung maupun tidak langsung; (3) dinamika kelompok, menunjukkan suasana yang menggambarkan sekelompok individu yang saling berinteraksi mengenai sesuatu yang sengaja dilihat atau dikaji bersama dengan berbagai ide dan pendapat serta saling tukar-menukar pengalaman dan saling berargumentasi.

Pada model ini para siswa dibebaskan membentuk kelompoknya sendiri yang terdiri dari lima sampai enam orang anggota yang heterogen dengan mempertimbangkan keakraban dan minat yang sama dalam topik tertentu. Berdasarkan penjelasan tersebut, maka dapat disimpulkan bahwa jumlah anggota tidak ditentukan atau 
harus sama dengan penjelasan di atas tergantung guru dan kondisi siswa. Kelompok ini kemudian memilih topik-topik dari unit yang telah dipelajari oleh seluruh kelas, membagi topik-topik ini menjadi tugas-tugas pribadi, dan melakukan kegiatan yang diperlukan untuk mempersiapkan laporan kelompok. Setiap kelompok lalu mempresentasikan atau menampilkan hasil penemuan mereka di depan kelas.

Arends mengemukakan enam tahap kegiatan dalam model pembelajaran Group Investigation yaitu:

a. Mengidentifikasi topik dan pembentukan kelompok.

Tahapan ini menekankan pada permasalahan dimana siswa meneliti, mengajukan topik dan saran. Peranan ini dimulai dengan setiap siswa diberikan modul dimana berisi kisi-kisi, dari langkah ini diharapkan siswa mampu menebak topik apa yang akan disampaikan siswa. Kemudian siswa yang memiliki topik yang sama dikelompokkan menjadi satu kelompok yang sama dalam penyelidikan nantinya. Dalam hal ini peran guru adalah membatasi jumlah kelompok serta membantu mengumpulkan informasi dan memudahkan pengaturannya.

b. Merencanakan tugas yang akan dipelajari.

Pada tahap ini anggota kelompok menentukan sub topik yang akan diinvestigasi dengan cara mengisi lembar kerja yang telah tersedia serta mengumpulkan sumber untuk menyelesaikan masalah yang telah diinvestigasi oleh kelompok kecil. Kemudian setiap kelompok memberikan kontribusi kepada kepala penelitian untuk seluruh kelas.

c. Melaksanakan investigasi.

Siswa secara individual atau berpasangan mengumpulkan informasi, menganalisa dan mengevaluasi serta menarik kesimpulan. Setiap anggota kelompok memberikan kontribusi satu dari bagian penting yang lain untuk kelompoknya. Anggota kelompok yang lain dapat menolong dan mendiskusikan 
pekerjaannya dengan mengadakan saling tukar informasi dan mengimpulkan ide-ide tersebut untuk menjadi satu kumpulan.

d. Menyiapkan laporan akhir.

Pada tahap ini merupakan tingkat pengorganisasian dengan mengintegrasikan semua bagian menjadi sebuah keseluruhan dan merencanakan suatu presentasi di depan kelas. Setiap kelompok telah menunjuk salah satu anggota untuk mempresentasikan tentang laporan hasil akhir penyelidikannya yang kemudian setiap anggotanya mendengarkan. Peran guru disini sebagai penasehat membantu memastikan setiap anggota kelompok ikut andil didalamnya.

e. Mempresentasikan hasil akhir.

Setiap kelompok telah siap memberikan hasil akhir di depan kelas dengan berbagai bentuk presentasi. Diharapkan dari penyajian presentasi yang beraneka ragam tersebut, kelompok lain dapat aktif mengevaluasi kejelasan dari laporan setiap kelompok dengan melakukan tanya jawab.

f. Mengevaluasi.

Pada tahap ini siswa memberikan tanggapan dari masing-masing topik pengalaman aktif mereka. Guru dan siswa lain berkolaborasi mengevaluasi proses belajar sehingga semua siswa diharapkan menguasai semua sub topik yang disajikan.

Dalam model Group Investigation ini guru hanya berperan sebagai mediator, fasilitator, dan pemberi kritik yang bersahabat. Seyogyanya guru membimbing dan mencerminkan kelompok melalui 3 tahap: (a) tahap pemecahan masalah; (b) tahap pengelolaan kelas; (c) tahap pemaknaan secara perorangan. Ditempuhnya 3 tahapan tersebut, diharapkan dalam pembelajaran dapat menghasilkan proses belajar yang lebih baik dan siswa lebih menyeluruh dalam mendalami materi yang disampaikan oleh guru. 
Model Group Investigation memiliki kelebihan dibandingkan dengan metode lainnya yaitu: (1) siswa menjadi lebih mandiri dalam mencari informasi tentang materi yang akan dipelajari; (2) siswa mempunyai jiwa kooperatif yang tinggi; (3) siswa memiliki kemahiran dalam berkomunikasi dengan intelektual pembelajaran dalam mensintesis dan menganalisis; (4) meningkatkan kemampuan siswa dalam berdiskusi.

Beberapa kelemahan dari metode Group Investigation yaitu: (1) jika ada seorang siswa yang tidak aktif dalam kelompoknya maka akan menghambat dari pada tujuan pembelajaran; (2) siswa yang tidak cocok dengan anggota kelompoknya kurang bisa bekerjasama dalam memahami materi maupun dalam menyelesaikan tugas; (3) ada siswa yang kurang memanfaatkan waktu sebaik-baiknya dalam belajar kelompok.

\section{Role Playing}

Role playing adalah sebuah permainan yang para pemainnya memainkan peran tokoh-tokoh khayalan dan berkolaborasi untuk merajut sebuah cerita bersama. Pada model bermain peran, siswa mengeksplorasi problem-problem relasi manusia dalam situasi masalah yang sedang berlangsung kemudian mendiskusikannya. Secara bersama-sama siswa dapat menggali perasaan, sikap, nilai-nilai dan strategi pemecahan masalah.

Bermain peran adalah sebuah model pembelajaran yang berakar pada dimensi pendidikan personal maupun sosial. Model ini akan membantu siswa secara individual menemukan makna personal dalam dunia personalnya dan memecahkan dilema personal dengan bantuan kelompok sosial. Dalam dimensi sosial, sangat memungkinkan siswa secara individual bekerja secara bersama-sama dalam menganalisis situasi sosial, khususnya masalah-masalah interpersonal dengan mengembangkan cara-cara secara demokratik mengatasi situasi yang demikian. 
Esensi bermain peran adalah melibatkan partisipan dan pengamat pada situasi problem nyata dan harapan pemahaman dan pemecahan masalah tersebut dengan melibatkan siswa. Proses bermain peran diharapkan merupakan contoh perilaku manusia dalam kehidupannya dengan tujuan untuk:

a. Menggali perasaan

b. Memperoleh inspirasi terhadap sikap, nilai-nilai, dan persepsi

c. Mengembangkan sikap dan kecakapan memecahkan masalah

d. Menggali inti pelajaran dengan berbagai cara.

Menurut Mulyasa, terdapat empat asumsi yang mendasari pembelajaran bermain peran untuk mengembangkan perilaku dan nilai-nilai sosial, yang kedudukannya sejajar dengan model-model mengajar lainnya. Keempat asumsi tersebut sebagai berikut:

a. Secara implisit bermain peran mendukung suatu situasi belajar berdasarkan pengalaman dengan menitikberatkan isi pelajaran pada situasi "di sini pada saat ini". Model ini percaya bahwa sekelompok siswa dimungkinkan untuk menciptakan analogi mengenai situasi kehidupan nyata. Terhadap analogi yang diwujudkan dalam bermain peran, para siswa dapat menampilkan respons emosional sambil belajar dari respons orang lain.

b. Bermain peran memungkinkan para siswa untuk mengungkapkan perasaannya yang tidak dapat dikenal tanpa bercermin pada orang lain. Bermain peran dalam konteks pembelajaran memandang bahwa diskusi setelah pemeranan dan pemeranan itu sendiri merupakan kegiatan utama dan integral dari pembelajaran.

c. Model bermain peran berasumsi bahwa emosi dan ide-ide dapat diangkat ke taraf sadar untuk kemudian ditingkatkan melalui proses kelompok. Pemecahan tidak selalu datang dari orang tertentu, tetapi bisa saja muncul dari reaksi pengamat terhadap masalah yang sedang diperankan. Dengan demikian, para siswa dapat belajar dari pengalaman orang lain tentang cara 
memecahkan masalah yang pada gilirannya dapat dimanfaatkan untuk mengembangkan dirinya secara optimal. Oleh sebab itu, model mengajar ini berusaha mengurangi peran guru yang terlalu mendominasi pembelajaran dalam pendekatan tradisional. Model bermain peran mendorong siswa untuk turut aktif dalam pemecahan masalah sambil menyimak secara seksama bagaimana orang lain berbicara mengenai masalah yang sedang dihadapi.

d. Model bermain peran berasumsi bahwa proses psikologis yang tersembunyi, berupa sikap, nilai, perasaan dan sistem keyakinan, dapat diangkat ke taraf sadar melalui kombinasi pemeranan secara spontan. Dengan demikian, para siswa dapat menguji sikap dan nilainya yang sesuai dengan orang lain, apakah sikap dan nilai yang dimilikinya perlu dipertahankan atau diubah. Tanpa bantuan orang lain, para siswa sulit untuk menilai sikap dan nilai yang dimilikinya.

Tujuan pendidikan adalah merefleksi beberapa asumsi tentang proses belajar melalui bermain peran. Diasumsikan bahwa bermain peran dapat memberdayakan pengalaman berdasarkan situasi belajar yang terjadi disuatu tempat dan menjadi isi pelajaran. Model ini mengasumsikan bahwa sangat mungkin menciptakan analogi secara otentik tentang problem kehidupan. Asumsi lainnya adalah bahwa gagasan dan emosi siswa dapat diarahkan menuju kesadaran yang lebih tinggi melalui kelompok. Proses-proses psikologis termasuk sistem keyakinan diri, nilai dari sikap diri, dapat ditingkatkan dengan cara analisis perilaku spontan saat bermain peran. Langkah-langkah dalam pembelajaran bermain peran adalah sebagai berikut:

Tahap 1: Persiapan Kelompok

1. Identifikasi atau memperkenalkan masalah

2. Mengekspilisitkan masalah 
3. Menggali issue utama

4. Penjelasan bermain peran

Tahap 2: Pemilihan Partisipan

1. Analisis peran

2. Memilih pemain peran

Tahap 3: Setting Tahapan Bermain

1. Setting aturan main

2. Penegasan peran

3. Menemukan masalah-masalah dari dalam yang mungkin terjadi pada situasi masalah

Tahap 4: Menyiapkan Pengamat

1. Menentukan apa yang harus dicari dalam pengamatan

2. Menandai lembar/tugas observasi

Tahap 5: Memerankan

1. Memulai bermain peran

2. Mengendalikan bermain peran

3. Menghentikan bermain peran

Tahap 6: Diskusi dan Evaluasi

1. Membahas permainan peran-peristiwanya, posisinya, dan realisasinya

2. Diskusi fokus utama

3. Pengembangan bermain peran berikutnya

Pada pelaksanaan model role playing, guru bertanggungjawab melakukan tahapan dan mengarahkan siswa melalui berbagai aktifitas dalam permainan. Isi diskusi dan permainan lebih cenderung ditentukan oleh siswa sendiri.

Guru juga membantu siswa menggali berbagai sisi situasi masalah dan membandingkan dengan pandangan-pandangan alternatif, meningkatkan kesadaran siswa pada pandangan dan perasaan mereka sendiri melalui refleksi, uraian kata-kata, dan kesimpulan dari tanggapan-tanggapannya. Menggunakan konsep peran, dan menekankan bahwa ada perbedaan cara untuk 
memainkan peran, menekankan bahwa ada berbagai cara untuk mengatasi masalah.

Kelebihan Role Playing melibatkan seluruh siswa berpartisipasi, mempunyai kesempatan untuk memajukan kemampuannya dalam bekerja sama. Siswa juga dapat belajar menggunakan bahasa dengan baik dan benar. Selain itu, kelebihan model ini adalah, sebagai berikut:

1. Siswa bebas mengambil keputusan dan berekspresi secara utuh.

2. Permainan merupakan penemuan yang mudah dan dapat digunakan dalam situasi dan waktu yang berbeda.

3. Guru dapat mengevaluasi pengalaman siswa melalui pengamatan pada waktu melakukan permainan.

4. Dapat berkesan dengan kuat dan tahan lama dalam ingatan siswa. Disamping merupakan pengalaman yang menyenangkan yang saling untuk dilupakan

5. Sangat menarik bagi siswa, sehingga memungkinkan kelas menjadi dinamis dan penuh antusias

6. Membangkitkan gairah dan semangat optimisme dalam diri siswa serta menumbuhkan rasa kebersamaan dan kesetiakawanan sosial yang tinggi.

7. Dapat menghayati peristiwa yang berlangsung dengan mudah, dan dapat memetik butir-butir hikmah yang terkandung di dalamnya dengan penghayatan siswa sendiri.

8. Dimungkinkan dapat meningkatkan kemampuan profesional siswa, dan dapat menumbuhkan/membuka kesempatan bagi lapangan kerja.

Sebuah ilmu yang tercipta oleh manusia tidak ada yang sempurna, semua ilmu ada kelebihan dan kekurangan. Jika kita melihat model Role Playing dalam cakupan cara proses mengajar dan belajar di lingkup pendidikan tentunya selain kelebihan terdapat kelemahan. Kelemahan role playing antara lain: 
1. Memerlukan waktu yang relatif panjang/banyak.

2. Memerlukan kreatifitas dan daya kreasi yang tinggi dari pihak guru maupun siswa, dan ini tidak semua guru memilikinya.

3. Kebanyakan siswa yang ditunjuk sebagai pemeran merasa malu untuk memerlukan suatu adegan tertentu.

4. Apabila pelaksanaan sosiodrama dan bermain pemeran mengalami kegagalan, bukan saja dapat memberi kesan kurang baik, tetapi sekaligus berarti tujuan pengajaran tidak tercapai.

5. Tidak semua materi pelajaran dapat disajikan melalui model ini.

3. Model Pembelajaran Inkuiri Yurisprudensial

Model pembelajaran Yurisprudensial dipelopori oleh Donal Oliver dan James P. Shaver dari Harvard yang didasari pada pemahaman bahwa setiap orang berbeda pandangan dan prioritas satu sama lain dengan nilai sosial saling berhadapan. Untuk memecahkan masalah yang ditimbulkan oleh perbedaan pandangan masyarakat, setiap anggota masyarakat dituntut untuk mampu berbicara dan bernegosiasi untuk mencapai kesepakatan.

Pendidikan harus mampu menghasilkan individu yang mampu mengatasi konflik perbedaan dalam berbagai hal. Model pembelajaran ini membantu siswa untuk belajar berpikir sistematis tentang isu-isu kontemporer dalam masyarakat. Dengan menganalisis dan mendiskusikan isu-isu sosial membantu siswa berpartisipasi dalam mendefinisikan ulang nilai-nilai sosial tersebut, sehingga siswa peka terhadap permasalahan sosial, berani mengambil sikap, mempertahankan sikap tersebut dengan argumentasi yang relevan dan valid. Siswa juga dituntut bisa menerima atau menghargai sikap orang lain yang mungkin berbeda dan bertentangan dengan sikapnya.

Sebelum mengambil sikap siswa harus mempunyai pengetahuan dibidang sejarah, sosiologi, ekonomi dan politik. Sehingga bidang kajian yang tepat untuk model pembelajaran 
Penelitian Yurisprudensial adalah konflik rasial, etnis, ideologi, keagamaan, keamanan, konflik antar golongan, ekonomi, kesehatan, pendidikan, kesejahteraan dan keamanan nasional.

Model Pembelajaran Inquiri Yurisprudensial memiliki enam tahap dalam pembelajaran (Joyce dan Weil, 1986) yaitu:

1. Pengenalan terhadap kasus

a) Guru memperkenalkan kasus kepada siswa atau isu terbaru dengan bercerita, memutar film atau mengambarkan kejadian hangat yang terjadi dalam masyarakat.

b) Guru mengkaji ulang data yang menggambarkan kasus.

2. Mengidentifikasi kasus

Siswa mensintesis fakta kedalam isu yang dihadapi, mengaitkan dengan isu umum dan mengidentifikasi nilai-nilai yang terlibat.

3. Menetapkan posisi

Siswa diminta untuk mengambil posisi mengenai isu tersebut dan menyatakan sikap menerima atau menolak.

4. Mengeksplorasi contoh dan argumentasi terhadap sikap

Siswa diminta menggali lebih dalam sikapnya dengan mengeksplorasi contoh dengan memberikan argumen logis dan rasional. Guru memberikan pertanyaan-pertanyaan konfrontatif kepada siswa tentang sikapnya. Siswa diuji konsistensi sikapnya dengan mempertahankan sikap dengan argumennya.

5. Menguji posisi

Jika argumen kuat, logis dan rasional maka siswa akan mempertahankan sikapnya (konsisten) dan posisi siswa dapat berubah (inkonsisten) jika argumen tidak kuat.

6. Menguji asumsi

Guru mendiskusikan apakah argumentasi yang digunakan untuk mendukung sikap relevan atau valid.

Kerangka kerja Yurisprudensial dibangun dengan asumsi akan ada dialog hangat, membuat situasi kurang dan lebih demokratis 
dengan pandangan kritis masing-masing dan pemikiran yang setara dan juga subjek sama-sama teliti. Iklim sosial akan terjadi untuk analisis kritis terhadap nilai yang hanya mungkin terbuka. Disinilah peran guru untuk menekankan jalannya dialog dengan enam operasional yang memainkan peran memimpin dan bertanggungjawab menjadikan debat solid dan isu dieksplorasi secara baik.

Guru menjamin iklim intelektual dalam diskusi sehingga semua pandangan yang diungkapkan siswa dihormati oleh siswa lain. Guru memelihara kekuatan intelektual dalam debat secara kontinyu yang menekankan pada enam langkah kerangka Yurisprudensial.

Dua jenis pendukung diperlukan dalam model pembelajaran Yurisprudensial. Guru meminta siswa untuk mengidentifikasi informasi yang difokuskan pada situasi masalah. Akses lain mengkondisikan siswa belajar nilai dan memiliki identifikasi etika dan posisi hukum yang dapat dibawa untuk mendukung dalam diskusi.

Model pembelajaran Yurisprudensial dirancang untuk mengajarkan secara langsung, komitmen terhadap peranan orang lain dan kemampuan untuk berdialog. Secara tidak langsung mempunyai kemampuan menganalisis isu-isu sosial, menghargai pluralisme, memahami fakta-fakta masalah sosial dan kemampuan berpartisipasi dan kesediaan untuk melakukan tindakan sosial.

Kelebihan model yurisprudensi sebagai berikut:

a. Memotivasi siswa untuk aktif menganalisis sebuah kasus sehingga tidak mudah menentukan sikap dan menyimpulkan tanpa dasar.

b. Memotivasi siswa untuk berdebat secara aktif dan memberi argumen logis dan rasional, sehingga meningkatkan kemampuan verbal siswa.

c. Mengembangkan keterbukaan dan menghargai perbedaan pendapat 
d. Mengembangkan pengetahuan dan wawasan siswa tentang sebuah kasus

e. Banyak isu sosial yang berkembang dalam masyarakat sehingga model ini mudah diterapkan untuk setiap kompetensi dasar.

Sementara itu, kelemahan model ini yaitu:

a. Membutuhkan implementasi yang cukup lama karena perubahan metode pembelajaran sebelumnya yang tidak menuntut keaktifan siswa.

b. Sulit untuk mengarahkan argumentasi siswa pada awalnya karena tidak semua siswa mempunyai pengetahuan yang cukup sehingga tidak menutup kemungkinan terjadi debat yang tak terarah.

\section{Model Pembelajaran Inquiry}

Model pembelajaran inquiry merupakan bagian inti dari kegiatan pembelajaran berbasis kontekstual. Pengetahuan dan keterampilan yang diperoleh siswa diharapkan bukan hasil mengingat seperangkat fakta-fakta, tetapi hasil dari menemukan sendiri. Guru harus selalu merancang kegiatan yang merujuk pada kegiatan menemukan, apapun materi yang diajarkan. Langkah-langkah kegiatan inquiry menurut Depdiknas (2002: 19) adalah sebagai berikut:

a. Merumuskan masalah

b. Mengamati atau melakukan observasi

c. Menganalisis dan menyajikan hasil dalam tulisan, gambar, laporan, bagan, tabel, dan karya lainnya

d. Mengkomunikasikan atau menyajikan hasil karya pada pembaca, teman sekelas, guru, atau audiens yang lain

Dari penjelasan di atas dapat disimpulkan bahwa inkuiri adalah bagian inti kegiatan yang berasal dari penemuan sendiri siswa dari 
materi yang telah disampaikan. Salah satu model pembelajaran yang sampai sekarang masih tetap dianggap sebagai model yang cukup efektif adalah model inquiry. Inquiry berkaitan dengan aktivitas dan keterampilan aktif yang fokus pada pencarian pengetahuan atau pemahaman untuk memuaskan rasa ingin tahu.

Model inquiry merupakan metode pembelajaran yang berupaya menanamkan dasar-dasar berfikir ilmiah pada diri siswa, sehingga dalam proses pembelajaran ini siswa lebih banyak belajar sendiri, mengembangkan kreatifitas dalam memecahkan masalah. Siswa benar-benar ditempatkan sebagai subjek yang belajar. Peranan guru dalam pembelajaran dengan model inquiry adalah sebagai pembimbing dan fasilitator.

Tugas guru adalah memilih masalah yang perlu disampaikan kepada kelas untuk dipecahkan. Namun dimungkinkan juga bahwa masalah yang akan dipecahkan dipilih oleh siswa. Tugas guru selanjutnya adalah menyediakan sumber belajar bagi siswa dalam rangka memecahkan masalah. Bimbingan dan pengawasan guru masih diperlukan, tetapi intervensi terhadap kegiatan siswa dalam pemecahan masalah harus dikurangi (Sagala, 2004).

Walaupun dalam praktiknya aplikasi model pembelajaran inquiry sangat beragam, tergantung pada situasi dan kondisi sekolah, namun dapat disebutkan bahwa pembelajaran dengan model inquiry memiliki 5 komponen yang umum yaituQuestion, Student Engangement, Cooperative Interaction, Performance Evaluation, dan Variety of Resources (Garton, 2005).

Question. Pembelajaran biasanya dimulai dengan sebuah pertanyaan pembuka yang memancing rasa ingin tahu siswa dan atau kekaguman siswa akan suatu fenomena. Siswa diberi kesempatan untuk bertanya, yang dimaksudkan sebagai pengarah ke pertanyaan inti yang akan dipecahkan oleh siswa. Selanjutnya, guru menyampaikan pertanyaan inti atau masalah inti yang harus dipecahkan oleh siswa. Untuk menjawab pertanyaan ini-sesuai 
dengan Taxonomy Bloom -siswa dituntut untuk melakukan beberapa langkah seperti evaluasi, sintesis, dan analisis. Jawaban dari pertanyaan ini tidak dapat ditemukan misalnya di dalam buku teks, melainkan harus dibuat atau dikonstruksi.

Student Engangement. Dalam metode inquiry, keterlibatan aktif siswa merupakan suatu keharusan sedangkan peran guru adalah sebagai fasilitator. Siswa bukan secara pasif menuliskan jawaban pertanyaan pada kolom isian atau menjawab soal-soal pada akhir bab sebuah buku, melainkan dituntut terlibat dalam menciptakan sebuah produk yang menunjukkan pemahaman siswa terhadap konsep yang dipelajari atau dalam melakukan sebuah investigasi.

Cooperative Interaction. Siswa diminta untuk berkomunikasi, bekerja berpasangan atau dalam kelompok, dan mendiskusikan berbagai gagasan. Dalam hal ini, siswa bukan sedang berkompetisi. Jawaban dari permasalahan yang diajukan guru dapat muncul dalam berbagai bentuk, dan mungkin saja semua jawaban benar.

Performance Evaluation. Dalam menjawab permasalahan, biasanya siswa diminta untuk membuat sebuah produk yang dapat menggambarkan pengetahuannya mengenai permasalahan yang sedang dipecahkan. Bentuk produk ini dapat berupa slide presentasi, grafik, poster, karangan, dan lain-lain. Melalui produk-produk ini guru melakukan evaluasi.

Variety of Resources. Siswa dapat menggunakan bermacam-macam sumber belajar, misalnya buku teks, website, televisi, video, poster, wawancara dan lain-lain. Tahap-tahap pemodelan Inquiry menurut Made Wena (2009:81) terdiri atas 6 tahapan, yaitu:

a. Tahap Orientasi

Tahap orientasi ini merupakan tahap awal dari model Inquiry ilmu sosial. Dalam tahap ini guru dituntut mampu membangun/mengembangkan rasa peka siswa terhadap masalah-masalah sosial atas objek yang dibahas. Kepekaan 
siswa mungkin akan muncul dari pengamatan situasi kehidupan sosial sehari-hari dari hasil refleksi terhadap suatu bacaan/topik, dari situasi konflik yang ada di masyarakjat, di kelas dan dari sejumlah sumber lain. Menurut Cardielo (1996: 14) bahwa "kriteria paling penting dalam tahap ini adalah semua aspek harus berpusat dari suatu masalah yang menjadi subjek pembelajaran. Dalam tahap ini guru diminta membantu siswa menjadi peka dan membantu siswa untuk mengembangkan kepekaannya terhadap permasalahan sosial yang dijumpai dalam kehidupan sehari-hari baik yang terjadi di sekolah maupun yang terjadi di masyarakat luas.

b. Tahap Pengembangan Hipotesis

Pada tahap pengembangan hipogtesis ini, guru diminta membantu siswa mengembangkan hipotesis yang berhubungan dengan masalah yang telah dirumuskan. Hipotesis-hipotesis yang diajukan oleh siswa kemudian diuji oleh guru dan oleh kelompok siswa lain terkait dengan validitas, kompabilitas, dan kesesuaian dengan fakta dan bukti yang mendukung atau bukti yang tidak mendukung.

c. Tahap Melakukan Definisi

Dalam tahap melakukan definisi ini, hipotesis yang diajukan diklarifikasi dan didefinisikan, sehingga semua kelompok siswa dapat memahami dan mengkomunikasikan permasalahan yang dibahas. Untuk tahap ini pendefinisian suatu konsep/teori harus menggunakan bahasa yang jelas dan mudah dipahami oleh siswa.

d. Tahap Melakukan Eksplorasi

Dalam tahap ini hipotesis yang diajukan diperluas/dianalisis, implikasinya, asumsi-asumsinya, dan deduksi yang mungkin dilakukan dari hipotesis tersebut. Dalam hal ini dilakukan kajian terhadap kualitas dan kekurangan hipotesis, yang diuji tingkat validitas logisnya dan konsistensi internalnya. Menurut Willen 
(1996: 29) bahwa "salah satu tujuan pembelajaran ilmu sosial adalah menumbuhkembangkan pengetahuan dan keterampilan siswa dalam melakukan eksplorasi terhadap gejala-gejala sosial yang multi kompleks.

e. Tahap Pembuktian

Data yang didapat pada tahap ini digunakan untuk mendukung hipotesis yang telah dikumpulkan, sesuai dengan karakteristik hipotesis yang diajukan. Dalam tahap ini siswa dibimbing cara-cara mengumpulkan bukti, fakta, data yang berhubungan dengan hipotesis yang diajukan. Menurut Joice \&Weil (1992: 12) bahwa "siswa didorong untuk belajar memverifikasi, mengklasifikasikan, mengkategorikan, dan mereduksi data-data".

f. Tahap Generalisasi

Tahap terakhir ini adalah pengungkapan penyelesaian masalah yang dipecahkan. Dari data-data (bukti, fakta) yang telah dikumpulkan dan dianalisis, siswa didorong untuk mencoba mengembangkan beberapa kesimpulan, dan dari berbagai kesimpulan yang telah dibuat, siswa diajar bagaimana memilih pemecahan masalah yang paling cepat.

Ada tiga ciri pokok dalam model mengajar inkuiri sosial yaitu:

a. Adanya aspek-aspek sosial dalam kelas yang dapat menumbuhkan terciptanya suasana diskusi kelas.

b. Adanya penetapan hipotesis sebagai arah dalam pemecahan masalah.

c. Mempergunakan fakta sebagai pengujian hipotesis.

Dalam pelaksanaan model mengajar dengan inkuiri sosial, para siswa diatur dalam bentuk struktur sosial yang sederhana. Mereka akan membentuk sistem sosial yang berubah atau bergerak dari tiap tahap ke tahap berikutnya. Norma-norma dalam inkuiri diusahakan 
agar tercipta diskusi secara bebas dan terbuka, serta memiliki rasa tanggung jawab untuk berusaha mengadakan penemuan sendiri.

Selama proses inkuiri, guru harus berperan sebagai seorang pembimbing, yaitu memberikan bantuan kepada para siswa dalam menjelaskan kedudukan mereka dalam proses belajarnya, cara-cara belajarnya dan dalam setiap penyusunan rencana yang akan mereka lakukan. Demikian pula guru harus dapat membantunya dalam merumuskan dan menjelaskan setiap istilah yang ada pada hipotesis maupun masalah, membantu dalam memilih dan menyusun asumsi-asumsi yang akan digunakan, serta cara diskusi dan berpikir efektif dan objektif. Peranan guru yang utama adalah sebagai reflektor bukan sebagaiinstruktor.

Hal yang sangat penting dalam melaksanakan model inkuiri adalah adanya kepercayaan dari guru, bahwa :

a. Pengembangan sesuatu penemuan dilakukan dengan tidak tergesa-gesa.

b. Pemecahan masalah dilakukan dengan pendekatan terhadap kehidupan.

c. Banyak sumber-sumber kepustakaan yang dapat digunakan dalam pengumpulan informasi yang diperlukan.

d. Mempergunakan pendapat ahli dan sumber lain di luar sekolahnya.

e. Suatu sumber yang kaya akan informasi yang sangat diperlukan dalam pelaksanaan inkuiri sosial yang betul-betul.

Ditinjau dari segi ilmu pengetahuan, khususnya mengenai prinsip-prinsip penelitian ilmiah, model inkuiri sangat cocok untuk penelaahan gejala-gejala sosial. Suatu kebenaran ilmiah dilakukan dengan pengujian logis dan pembuktian empiris. Dalam inkuiri sosial hal ini dilakukan oleh para siswa. Dengan demikian keuntungan lain dari inkuiri sosial, para siswa terlatih dalam menemukan dan mempergunakan prinsip-prinsip penelitian ilmiah. 
Kelebihan lain dari inquiry sosial adalah para siswa dapat berpikir dan mencari sendiri dalam situasi bebas yang terarah (adanya hipotesis), sehingga hal ini akan menimbulkan semangat belajar pada siswa.

Selain memiliki kelebihan, model inkuiri juga memiliki kelemahan. Pelaksanaan inkuiri sosial memerlukan waktu yang lama serta usaha yang tinggi dari para siswa. Jika para siswa tidak memiliki kesadaran dan usaha yang tinggi, pelaksanaan inkuiri sosial tidak akan mencapai hasil sebagai model mengajar yang baik. Dengan waktu yang lama para siswa tidak akan segera mendapatkan pengetahuannya. Padahal para siswa dituntut untuk belajar memperoleh pengetahuan yang luas ruang lingkupnya.

\section{BAB 5 \\ MEDIA PEMBELAJARAN IPS SD}

Bab ini memuat materi tentang ragam media pembelajaran IPS di SD. Saat selesai mempelajari materi ini, pembaca diharapkan mampu:

1. Mendefinisikan media pembelajaran dengan kalimat sendiri

2. Menjelaskan peran media dalam proses pembelajaran

3. Memberi contoh ragam media pembelajaran

4. Menganalisis kelebihan dan kelemahan masing-masing media pembelajaran

5. Memilih media yang tepat untuk pembelajaran IPS SD Kelas awal 


\section{A. PENGERTIAN MEDIA}

Secara harafiah kata "media" berasal dari bahasa Latin, yang merupakan bentuk jamak dari "medium" yang berarti perantara atau alat (sarana) untuk mencapai sesuatu. Assosistion for Education and Communication Technology (AECT) mendifinisikan media adalah segala bentuk yang dipergunakan untuk suatu proses penyaluran informasi. Sedangkan Education Assiciation (NEA) mendefinisikan media sebagai benda yang dapat dimanipulaksikan, dilihat, didengar, dibaca atau dibicarakan beserta instrumen yang dipergunakan dengan baik dalam kegiatan belajar mengajar, sehingga dapat mempengaruhi efektifitas program instruksional.

Dapat disimpulkan bahwa media merupakan sesuatu yang bersifat menyalurkan pesan dan dapat merangsang pikiran, perasaan, dan kemauan, sehingga dapat terjadi proses belajar pada 
dirinya. Penggunaan media secara efektif memungkinkan dapat belajar lebih baik dan dapat meningkatkan performan mereka sesuai dengan tujuan yang akan dicapai.

Dengan demikian dapat disimpulkan bahwa yang dimaksud media adalah alat atau sarana yang digunakan sebagai perantara (medium) untuk menyampaikan pesan dalam mencapai tujuan pembelajaran. Pembelajaran merupakan proses komunikasi yang didalamnya ada unsur-unsur: sumber pesan (guru), penerima pesan (siswa), dan pesan yaitu materi pelajaran yang diambil dari kurikulum. Sumber pesan harus melakukan enconding, yaitu menerjemahkan gagasan, pikiran, perasaan atau pesannya ke dalam bentuk lambang tertentu. Lambang tersebut dapat berupa bahasa, tanda-tanda atau gambar.

Dalam melakukan enconding, guru harus memperhatikan latar belakang pengalaman penerima pesan, agar pesan tersebut mudah diterima. Di lain pihak penerima pesan harus melakukan decoding, yaitu menafsirkan lambang-lambang yang mengandung pesan. Apabila pesan/pengertian yang diterima oleh penerima pesan sama atau mendekati sama dengan pesan/pengertian yang dimaksud oleh sumber pesan (guru), maka komunikasi dapat dikatakan efektif. Media dapat membantu guru menyalurkan pesan. Semakin baik medianya, makin kecil distorsi/gangguannya, makin baik pesan tersebut diterima .

Di dalam proses belajar mengajar dewasa ini, masih banyak guru-guru yang enggan memanfaatkan media yang tersedia. Tetapi terjadi kecenderungan para dibiasakan sekedar mendengarkan apa yang diajarkan oleh guru, kemudian mencatat, dan dipaksa menghafalkan di luar kepala, atau sering dikenal dengan istilah duduk, dengar, catat, hafal. Keadaan seperti ini akan menghasilkan sikap verbalisme yang mengakibatkan hanya pasif di dalam proses belajar mengajar. 
Pada hakikatnya proses pembelajaran adalah proses komunikasi, kegiatan di kelas merupakan tempat guru dan melakukan tukar pikiran dan mengembangkan ide-idenya. Dalam berkomunikasi sering terjadi penyimpanganpenyimpangan sehingga komunikasi menjadi tidak efektif karena adanya kecenderungan verbalisme, ketidaksiapan, dan kurangnya minat. Salah satu usaha mengatasinya adalah dengan menggunakan media secara terintegrasi dalam proses pembelajaran. Hal ini disebabkan fungsi media dalam kegiatan pembelajaran disamping sebagai penyaji stimulus informasi dan sikap, juga untuk meningkatkan keserasian dalam penerimaan informasi. Dalam hal-hal tertentu media juga berfungsi untuk mengatur langkah-langkah kemajuan serta memberikan umpan balik.

Sejalan dengan perubahan pandangan tentang pengertian belajar mengajar, maka berubah pula pandangan terhadap media. Dewasa ini media tidak lagi dipandang hanya sebagai alat bantu yang digunakan jika perlu atau sekedar selingan, melainkan dipandang sebagai komponen dari sistem instruksional. Oleh karena itu penggunaan media harus dirancang, disiapkan, dipilih dan disusun secara cermat sesuai dengan tujuan instruksional yang hendak dicapai. Sebagai salah satu komponen sistem, maka media ikut mempengaruhi bekerjanya komponen lain, dengan demikian ikut menentukan keberhasilan proses pembelajaran. Dapat disimpulkan bahwa media bukan lagi sekedar sebagai alat bantu, tetapi merupakan bagian integral dari sistem instruksional. Maka penggunaan media dalam proses pembelajaran mutlak diperlukan.

Levie \& Lentz (1982) mengemukakan bahwa ada empat fungsi media pembelajaran, khususnya media visual. Keempat fungsi tersebut yaitu fungsi atensi, afektif, kognitif, dan kompensatoris. Fungsi atensi artinya media berfungsi menarik dan mengarahkan perhatian siswa agar berkonsentrasi kepada isi pelajaran. Fungsi afektif maknanya media dapat mengunggah emosi dan sikap siswa. Fungsi kognitif yaitu media memperlancar pencapaian tujuan untuk 
memahami dan mengingat informasi atau pesan yang terkandung dalam media. Terakhir, fungsi kompensatoris yang maksudnya adalah media mengakomodasikan siswa yang lemah dan lambat menerima dan memahami isi pelajaran yang hanya disajikan secara verbal.

Salah satu teori yang paling banyak dijadikan acuan sebagai landasan teori penggunaan media dalam proses belajar adalah Kerut Pengalaman Dale. Berdasarkan konkret abstraknya gambar yang disajikan, kerucut Edgar Dale menggambarkan tingkat-tingkat pengalaman sebagai berikut:
a. Pengalaman langsung
b. Pengalaman tiruan
c. Pengalaman dramatisasi
d. Demonstrasi
e. Karyawisata
f. Pameran
g. Televise
h. Gambar hidup atau film
i. Rekaman, radio, gambar tetap / diam; gambar
j. Lambang visual, seperti :bagan, grafik, peta
k. Lambang kata, seperti : membaca, mendengarkan, bicara

Dale (1969) menyatakan bahwa bahan audio visual dapat sangat bermanfaat asallkan guru dapat aktif berperan dalam pembelajaran. Elemen paling penting dalam sistem penbdidikan modern saat ini yaitu hubungan guru-siswa. Guru harus selalu hadir untuk menyajikan materi pelajaran dengan menggunakan media apapun yang sesuai untuk pencapaian tujuan pembelajaran.

Sudjana dan Rivai (1992) mengemukakan manfaat media pembelajaran. Menurutnya, dengan kehadiran media, pembelajaran akan lebih menarik perhatian siswa sehingga motivasi belajar siswa akan semakin meningkat. Media pembelajaran juga memperjelas 
bahan/materi yang abstrak sehingga siswa lebih mudah memahami materi dan memungkinkan untuk menguasai serta mencapai tujuan pembelajaran.

Selain itu, penggunaan media pembelajaran juga berfungsi sebagai variasi metode mengajar sehingga yang dilakukan guru tidak terbatas pada komunikasi verbal saja untuk membelajarkan siswanya. Dengan media, siswa menjadi tidak bosan dan guru tidak kehabisan tenaga karena berbagai penjelasan guru dapat terwakilkan melalui hadirnya media.

Fungsi yang tidak kalah penting dari sebuah media pembelajaran yaitu siswa menjadi lebih aktif dan lebih banyak melakukan kegiatan belajar. Siswa tidak hanya mendengarkan uraian guru, tetapi juga aktivitas lain seperti mengamati, memerankan, dan lain-lain.

Dari beberapa uraian di atas, dapat disimpulkan beberapa manfaat media pembelajaran yaitu memperjelas penyajian pesan; meningkatkan atensi siswa; mengatasi keterbatasan indera, ruang, dan waktu; dan memberikan pengalaman belajar bagi siswa.

\section{B. MACAM-MACAM MEDIA PEMBELAJARAN}

Dalam rangka pengajaran IPS banyak sekali media yang dapat dipakai. Karena beranekaragamnya media yang dapat dipakai, maka dapat dilakukan berbagai macam penggolongan atas dasar kategori tertentu. Menurut Hamalik ada 4 klasifkasi media pengajaran antara lain:

1. Alat-alat visual yang dapat dilihat, misalnya filmstrip, transparansi, micro projection, gambar, ilustrasi, chart, grafik, poster, peta, dan globe.

2. Alat-alat yang bersifat auditif atau hanya dapat didengar, misalnya transkripsi electris, radio, rekaman pada tape recorder.

3. Alat-alat yang dapat dilihat dan didengar, misalnya, film, televisi, benda-benda tiga dimensi yang biasanya dipertunjukkan (model, bak pasir, peta elektris, koleksi diorama). 
4. Dramatisasi, bermain peran, sosiodrama, sandiwara boneka, dan sebagainya.

Disamping itu media pengajaran juga dapat digolongkan atas kategori-kategori sebagai berikut :

1. Berdasarkan atas penggunaannya, media pengajaran terdiri dari:

a. Media yang tidak diproyeksikan (non-projected). Terdiri dari: papan tulis, gambar, peta, globe, foto, model (mock-up), sketsa, diagram, grafik.

b. Media yang diproyeksikan (projected). Terdiri dari: slide, filmstrip, Overhead Proyector (OHP, Micro Projection).

2. Berdasarkan atas gerakannya, media pengajaran terdiri dari:

a. Media yang tidak bergerak (still). Terdiri dari: filmstrip, OHP, micro projector.

b. Media yang bergerak (motion). Terdiri dari: film loop, TV, Vidio tape, dan sebagainya.

3. Berdasarkan fungsinya:

a. Visual media, media untuk dilihat seperti, gambar, foto, bagan, skema, grafik, film, slide.

b. Audio media, yaitu media untuk didengarkan seperti: radio, piringan hitam, tape recorder.

c. Gabungan a dan b: misalnya film bicara, TV, videotape.

d. Print media: misalnya barang-barang cetak, buku, surat kabar, majalah, buletin.

e. Dispay media, seperti: papan tulis, papan buletin, papan flannel.

f. Pengalaman sebenarnya dan tiruan, misalnya praktikum, permainan, karyawisata, dramatisasi, simulasi.

\section{PERTIMBANGAN PEMILIHAN MEDIA PEMBELAJARAN}

Media sebagai salah satu sarana dalam rangka membantu meningkatkan proses pembelajaran, mempunyai aneka ragam jenis 
dan karakteristik yang berbedabeda. Oleh karena itu seorang guru professional seharusnya memiliki kemampuan memilih secara cermat dan dapat menggunakan media pengajaran secara tepat. John Jarolimek mengemukakan hal-hal yang hendaknya diperhatikan oleh guru dalam menentukan pemilihan media, yaitu:

1. Tujuan pembelajaran yang akan dicapai,

2. Tingkat usia dan kematangan anak,

3. Kemampuan baca anak,

4. Tingkat kesulitan dan jenis konsep pelajaran, dan

5. Keadaan/latar belakang pengetahuan atau pengalaman anak

Beberapa pertimbangan lain yang juga perlu diperhatikan dalam memilih media, antara lain:

1. Media yang dipilih hendaknya selaras dan menunjang tujuan pembelajaran yang telah ditetapkan. Tujuan pembelajaran merupakan komponen utama yang harus diperhatikan dalam memilih media. Dalam penerapan media harus jelas dan operasional, spesifik, dan benar-benar tergambar dalam bentuk perilaku.

2. Aspek materi, merupakan hal yang perlu dipertimbangkan dalam memilih media. Sesuai tidaknya antara materi dengan media yang digunakan akan berdampak pada hasil pembelajaran.

3. Kondisi, dari segi subyek belajar, guru harus memperhatikan betul-betul tentang kondisi dalam memilih media. Misalnya faktor umur, intelegensi, latar belakang, budaya, dan lingkungan anak menjadi titik perhatian dan pertimbangan dalam memilih media.

4. Ketersediaan media di sekolah atau memungkinkan bagi guru untuk mendesain sendiri media yang akan dipergunakan, merupakan hal yang perlu dipertimbangkan oleh guru. Seringkali guru menganggap bahwa suatu media sangat tepat digunakan untuk suatu pokok bahasan/tema tertentu, tetapi disekolah 
tersebut tidak tersedia media yang diperlukan. Sedangkan untuk mendesain atau merancang suatu media yang dikehendaki tidak mungkin dilakukan oleh guru.

5. Media yang dipilih hendaknya dapat menjelaskan apa yang akan disampaikan kepada secara tepat, dalam arti tujuan yang ditetapkan dapat tercapai secara optimal.

6. Biaya yang akan dikeluarkan dalam pemanfaatan media harus seimbang dengan hasil yang akan dicapai. Media sederhana mungkin akan lebih menguntungkan dari pada menggunakan media canggih tetapi hasil yang dicapai tidak sebanding dengan dana yang dikeluarkan.

\section{BAB 6}

\section{PENILAIAN PEMBELAJARAN IPS SD KELAS AWAL}

Bab ini berisi materi tentang evaluasi pemblajaran IPS SD kelas awal. Pembaca yang telah mempelajari materi ini diharapkan mampu:

1. Menjelaskan pengertian penilaian pembelajaran

2. Menguraikan teknik-teknik penilaian pembelajaran

3. Memberi contoh berbagai alat penilaian pembelajaran

4. Mengaplikasikan penilaian dalam pembelajaran IPS di SD kelas awal 


\section{A. PENGERTIAN EVALUASI PEMBELAJARAN}

Sebagai sebuah sistem, masing-masing komponen dalam pembelajaran tentu memiliki keterkaitan. Komponen tersebut meliputi tujuan, kegiatan pembelajaran, materi, media dan evaluasi. Sebelum melaksanakan kegiatan pembelajaran, seorang guru harus menentukan tujuan apa yang hendak dicapai. Tujuan tersebut kemudian menjadi arah untuk menentukan langkah pembelajaran yang harus ditempuh, materi apa yang sesuai, serta media apa yang diperlukan. Lantas, bagaimana cara mengetahui sudah mencapai tujuan? Hal ini berkaitan dengan penilaian.

Saat membicarakan penilaian dalam pembelajaran, kita sering rancu dengan istilah pengukuran, penilaian, dan evaluasi. Banyak orang yang menganggap tidak ada perbedaan makna dari ketiga istilah tersebut. Hal ini dapat dipahami karena antara ketiga istilah tersebut terdapat keterkaitan satu sama lain.

Pengukuran (measurement) menurut Cangelosi (1991) adalah proses pengumpulan data melalui pengamatan empiris. Grondlund \& Linn (1996) menyatakan bahwa "measurement is limited to quantitative descriptions of pupils, that is, the results of 
measurements are always expressed in numbers." Rumusan yang sama disampaikan oleh Woolfolk (2007). Dia menyatakan bahwa "measurement is quantitative- the description of an event or characteristic using number."

Dapat disimpulkan, pengukuran pada dasarnya merupakan kauntifikasi atau kegiatan penentuan/penetapan angka dari suatu objek yang diukur menurut aturan tertentu. Untuk dapat memperoleh hasil pengukuran, tentulah kita memerlukan alat ukur. Alat ukur tidak selalu berupa tes, tetapi bisa juga non tes. Pemilihan alat ukur hendaknya disesuaikan dengan objek yang hendak diukur.

Penilaian (assessment) adalah kegiatan untuk mengumpulkan informasi hasil belajar yang diperoleh dari berbagai jenis tagihan dan mengolah informasi tersebut untuk menilai hasil belajar dan perkembangan belajar (Suryanto, 2012). Sementara itu, penilaian hasil belajar menurut kurikulum 2013 yaitu proses pengumpulan informasi/bukti tentang capaian pembelajaran siswa dalam kompetensi sikap spiritual dan sikap sosial, kompetensi pengetahuan, dan kompetensi ketrampilan yang dilakukan secara terencana dan sistematis, selama dan setelah proses pembelajaran.

Penilaian pada dasarnya merupakan pengolahan informasi yang diperoleh dari hasil pengukuran sehingga hasil tersebut memiliki makna. Hasil yang diperoleh melalui kegiatan pengukuran dengan menggunakan berbagai alat ukur hanyalah sekedar angka jika tidak dimaknai. Dapat disimpulkan, penilaian merupakan pemberian makna hasil suatu pengukuran berdasarkan kriteria tertentu.

Makna tersebut tergantung pada kriteria atau tujuan tertentu. Jika tujuan penilaian untuk menentukan ketercapaian, maka makna sebuah skor bisa "tercapai", "kurang", atau "tidak tercapai". Makna yang lain bisa lulus atau tidak lulus, diterima atau ditolak, tergantung dari tujuan/kriteria yang ditetapkan.

Evaluasi merupakan proses mengumpulkan, memaknai, dan menyajikan informasi secara sistematis dan berkelanjutan sebagai 
dasar pengambilan keputusan dan penentuan program selanjutnya. Suryanto (2012) menyatakan bahwa tujuan evaluasi yaitu meningkatkan kualitas, kinerja, atau produktivitas suatu lembaga dalam melaksanakan programnya.

Ruang lingkup evaluasi lebih luas dari penilaian. Jika penilaian hanya mencakup satu aspek, maka ruang lingkup evaluasi yaitu keseluruhan program. Dalam konteks pembelajaran, cakupan penilaian hanya pada individu dalam kelas, sedangkan cakupan evaluasi yaitu mulai dari input, proses, sampai pada hasil pembelajaran.

Dari uraian tersebut, dapat diketahui bahwa pengukuran, penilaian, dan evaluasi sangat erat keterkaitannya. Ketiganya bersifat hierarkis. Agar bisa melakukan evaluasi, harus didahului dengan penilaian. Sebelum melakukan penilaian, pengukuran terlebih dahulu dilakukan. Untuk bisa melakukan pengukuran, maka kita memerlukan sebuah alat ukur. Alat ukur tersebut dapat berupa instrumen tes maupun non tes.

Sebagai contoh, seorang guru mengadakan tes untuk memperoleh informasi hasil belajar pada mata pelajaran IPS. Data hasil belajar yang diperoleh merupakan hasil pengukuran dengan menggunakan alat ukur berupa tes. Jika tes dilakukan beberapa kali, maka guru akan memiliki kumpulan data hasil belajar pada mata pelajaran IPS.

Dari hasil belajar siswa, maka guru bisa memberi makna/menilai kualitas siswa tersebut, apakah mengalami peningkatan atau malah sebaliknya. Kemudian, dari penilaian menyeluruh, guru bisa mengambil keputusan apakah siswa tersebut mengikuti remidi atau tidak, dan guru juga bisa menentukan hal apa saja yang perlu dipertahankan atau diperbaiki.

Penilaian dalam kurikulum 2013 di SD, memiliki karakteristik sebagai berikut:

1. Belajar Tuntas 
Ketuntasan belajar merupakan tingkat minimal pencapaian kompetensi sikap, pengetahuan, dan keterampilan meliputi ketuntasan substansi dan ketuntasan belajar dalam kurun waktu belajar. Pada kompetensi sikap (KI-1 dan $\mathrm{KI}-2)$, pemberian umpan balik dan pembinaan sikap dilakukan secara langsung ketika perilaku siswa tidak mencapai kriteria baik. Siswa yang belum mencapai ketuntasan belajar pada $\mathrm{KI}-3$ dan $\mathrm{KI}-4$, diberi kesempatan untuk ramedi, dan siswa tidak diperkenankan melanjutkan pembelajaran kompetensi selanjutnya sebelum kompetensi tersebut tuntas.

Kriteria ketuntasan dijadikan acuan oleh guru untuk mengetahui kompetensi yang sudah atau belum dikuasai siswa. Melalui cara tersebut, guru mengetahui sedini mungkin kesulitan siswa sehingga pencapaian kompetensi yang kurang optimal dapat segera diperbaiki.

2. Autentik

Memandang penilaian dan pembelajaran sebagai dua hal yang saling berkaitan. Penilaian autentik harus mencerminkan masalah dunia nyata, bukan dunia sekolah. Menggunakan berbagai cara dan kriteria holistik (kompetensi utuh merefleksikan pengetahuan, keterampilan, dan sikap). Penilaian autentik tidak hanya mengukur apa yang diketahui oleh siswa, tetapi lebih menekankan mengukur apa yang dapat dilakukan oleh siswa.

3. Berkesinambungan

Penilaian berkesinambungan dimaksudkan sebagai penilaian yang dilakukan secara terus menerus dan berkelanjutan selama pembelajaran berlangsung. Tujuannya adalah untuk mendapatkan gambaran utuh mengenai perkembangan hasil belajar siswa, memantau proses, kemajuan, dan perbaikan hasil terus menerus dengan menggunakan berbagai bentuk penilaian. 
4. Menggunakan Bentuk Penilaian yang bervariasi

Penilaian pada kompetensi sikap, pengetahuan, dan keterampilan menggunakan berbagai bentuk penilaian yang sesuai dengan karakteristik kompetensi yang akan diukur atau dinilai. Berbagai bentuk penilaian yang dapat digunakan antara lain tes tertulis, tes lisan, penilaian produk, penilaian portofolio, kinerja, proyek, dan pengamatan atau observasi.

5. Berdasarkan Acuan Kriteria

Penilaian pada kompetensi sikap, pengetahuan, dan keterampilan menggunakan acuan kriteria. Kemampuan siswa tidak dibandingkan terhadap kelompoknya, tetapi dibandingkan terhadap ketuntasan yang ditetapkan. Idealnya, kriteria ketuntasan ditetapkan oleh satuan pendidikan dengan mempertimbangkan karakteristik kompetensi dasar yang akan dicapai, daya dukung (sarana dan guru), dan karakteristik siswa.

Selain karakteristik di atas, dalam melaksanakan penilaian hasil belajar pada pembelajaran IPS, guru perlu memperhatikan prinsip-prinsip penilaian sebagai berikut:

a. Valid/sahih

Penilaian harus mengukur pencapaian kompetensi yang ditetapkan dalam standar isi (standar kompetensi dan kompetensi dasar) dan standar kompetensi lulusan. Penilaian valid berarti menilai apa yang seharusnya dinilai dengan menggunakan alat yang sesuai untuk mengukur kompetensi.

b. Objektif dan Adil

Penilaian tidak menguntungkan atau merugikan siswa dan tidak dipengaruhi oleh subyektivitas penilai, perbedaan latar belakang agama, sosial-ekonomi, budaya, bahasa, gender, dan hubungan emosional.

c. Transparan/terbuka 
Penilaian hasil belajar oleh guru bersifat terbuka artinya prosedur penilaian, kriteria penilaian dan dasar pengambilan keputusan terhadap hasil belajar siswa dapat diketahui oleh semua pihak yang berkepentingan.

d. Terpadu

Penilaian merupakan salah satu komponen yang tak terpisahkan dari kegiatan pembelajaran.

e. Menyeluruh dan berkesinambungan

Penilaian mencakup semua aspek kompetensi dengan menggunakan berbagai teknik penilaian yang sesuai, untuk memantau perkembangan kemampuan siswa.

f. Sistematis

Penilaian dilakukan secara berencana dan bertahap dengan mengikuti langkah-langkah baku.

g. Bermakna

Penilaian hendaknya mudah dipahami, mempunyai arti, bermanfaat, dan dapat ditindaklanjuti oleh semua pihak, terutama guru, siswa, dan orangtua serta masyarakat.

h. Akuntabel

Penilaian hasil belajar oleh guru dapat dipertanggungjawabkan, baik dari segi teknik, prosedur, maupun hasilnya.

i. Beracuan kriteria

Penilaian didasarkan pada ukuran pencapaian kompetensi yang ditetapkan.

Saat membicarakan tentang penilaian, banyak orang beranggapan bahwa tes adalah satu-satunya cara menilai kemampuan siswa. Padahal, pelaksanaan pembelajaran tidak hanya terfokus pada aspek kognitif saja, melainkan juga harus mampu mengembangkan kompetensi pada aspek sikap dan ketrampilannya. Teknik tes kurang cocok jika digunakan untuk menilai aspek selain 
pengetahuan. Tiap aspek kompetensi memiliki karakteristik yang berbeda sehingga perlu teknik yang berbeda pula pada penilaiannya.

Tidak ada satupun teknik penilaian yang mampu menilai segala aspek kompetensi. Tidak ada pula teknik penilaian yang terbaik sehingga bisa selalu digunakan. Setiap teknik penilaian memiliki kelebihan dan kekurangan masing-masing. Pemilihan teknik penilaian harus disesuaikan dengan aspek yang akan dinilai.

Secara garis besar, teknik penilaian dapat berupa tes dan non-tes. Penggunaan setiap teknik berbeda-beda. Tes umumnya digunakan untuk menilai aspek kognitif, sedangkan teknik non-tes cocok digunakan untuk menilai aspek afektif dan ketrampilan. Ada beragam teknik penilaian non-tes, seperti observasi, penilaian portofolio, penilaian diri, dan penilaian antar teman. Mardapi (2008) mengartikan tes sebagai salah satu cara untuk menaksir besarnya kemampuan seseorang secara tidak langsung melalui respons seseorang terhadap stimulus atau pertanyaan.

\section{B. BENTUK PENILAIAN PEMBELAJARAN}

Penilaian pembelajaran IPS di SD dilakukan dengan menggunakan berbagai bentuk penilaian untuk semua kompetensi dasar yang dikategorikan dalam tiga kompetensi, yaitu sikap, pengetahuan, dan keterampilan.

\section{Penilaian Kompetensi Sikap}

Sikap merupakan kecenderungan untuk berbuat dan berperilaku kepada suatu objek. Penilaian sikap dimaksudkan sebagai penilaian terhadap perilaku peserta didik dalam proses pembelajaran. Penilaian sikap memiliki karakteristik yang berbeda dari penilaian pengetahuan dan tekerampilan, seningga pendekatan dan bentuk penilaian yang digunakan juga berbeda. Dalam hal ini, penilaian sikap lebih ditujukan untuk membina perilaku sesuai budi pekerti dalam rangka pembentukan karakter peserta didik. 
Penilaian kompetensi sikap dilakukan melalui observasi, rubrik, wawancara, penilaian diri, penilaian antarteman, jurnal selama proses pembelajaran berlangsung, dan tidak hanya di dalam kelas. Penilaian kompetensi sikap menggunakan deskripsi yang menggambarkan perilaku peserta didik. Penilaian terhadap kompetensi sikap meliputi beberapa aspek, antara lain:

a. Kompetensi Sikap Spiritual

Aspek penilaian kompetensi sikap spiritual (KI-1), antara lain: (1) ketaatan beribadah; (2) berperilaku syukur; (3) berdoa sebelum dan sesudah melakukan kegiatan; dan (4) toleransi dalam beribadah. Kompetensi sikap spiritual tersebut dapat diganti dari yang ada dan ditambah sesuai karakteristik satuan pendidikan. Aspek tersebut berlaku untuk semua muatan pelajaran.

b. Kompetensi Sikap Sosial

Aspek penilaian sikap sosial (KI-2) meliputi: (1) jujur; (2) disiplin;

(3) tanggung jawab; (4) santun; (5) peduli; (6) percaya diri.

Penilaian sikap sosial dapat dilakukan dalam penilaian diri dan penilaian teman. Instrumen penilaian diri dan teman disiapkan oleh pendidik dalam bentuk esai, rubrik, atau portofolio. Stimulus atau lontaran yang diberikan pendidik hendaknya dalam rangka pembentukan kesadaran, kepedulian, dan sikap sosial serta emosional peserta didik. Hasil observasi atau penilaian sikap digunakan sebagai pelengkap atau penguatan hasil pengamatan oleh pendidik.

2. Penilaian Kompetensi Pengetahuan

Penilaian kompetensi pengetahuan (KI-3) pada pembelajaran IPS, dilakukan dengan menggunakan berbagai bentuk penilaian. Guru diharapkan mampu mengidentifikasi setiap KD atau materi pembelajaran IPS untuk selanjutnya memilih bentuk penilaian yang 
sesuai dengan karakteristik kompetensi yang akan dinilai. Penilaian dimulai dengan perencannaan yang dilakukan pada saat menyusun rencana pelaksanaan pembelajaran (RPP). Penilaian $\mathrm{KI}-3$ menggunakan predikat A (Sangat Baik); B (Baik); C (Cukup); D (Kurang); dan deskripsi.

Bentuk penilaian yang digunakan sebagai berikut:

a. Tes Tertulis

Tes tertulis adalah tes yang soal dan jawaban serta dilaksanakan secara tertulis berupa pilihan ganda, isian, benar-salah, menjodohkan, dan uraian. Instrumen tes tertulis dikembangkan atau disiapkan berdasarkan langkah-langkah berikut ini:

- Menetapkan tujuan tes, misal ulangan harian, ulangan tengah semester (UTS), dan ulangan akhir semester (UAS).

- Menyusun kisi-kisi sesuai dengan tujuan pembelajaran. Di dalam kisi-kisi ini memuat rambu-rambu tentang kriteria soal yang akan ditulis, misalnya bentuk soal, jumlah soal, KD yang akan diukur, materi, dan indikator soal. Dengan adanya kisi-kisi, penulisan soal lebih terarah karena sesuai dengan tes dan proporsi soal per KD atau materi yang hendak diukur lebih tepat.

- Menulis soal berdasarkan kisi-kisi dan kaidah penulisan soal.

- Menyusun pedoman penskoran sesuai dengan soal yang digunakan. Untuk soal pilihan ganda, isian, menjodohkan, dan jawaban singkat disediakan kunci jawaban. Untuk uraian disediakan pedoman penskoran berupa rentang skor (rubrik).

b. Tes Lisan

Tes lisan berupa pertanyaan-pertanyaan yang diberikan guru secara lisan dan peserta didik merespon pertanyaan tersebut secara lisan sehingga menumbuhkan sikap berani berpendapat. Jawaban dapat berupa kata, frase, kalimat, maupun paragraf. Sebelum pelaksanaan tes lisan, pendidik perlu membuat perencanaan yang meliputi tujuan tes dan materi soal. 


\section{c. Penugasan}

Penugasan adalah pemberian tugas kepada peserta didik untuk meningkatkan pengetahuan dari materi yang sudah dipelajari. Pemberian tugas dapat juga diberikan pada materi yang akan dipelajari sebagai bentuk stimulus pada peserta didik. Penugasan ini dapat dilakukan baik secara individu ataupun kelompok sesuai karakteristik materi tugas yang diberikan.

\section{Penilaian Kompetensi Keterampilan}

Penilaian kompetensi keterampilan (KI-4) dilakukan dengan mengidentifikasi karakteristik kompetensi yang ada untuk menentukan bentuk penilaiana yang sesuai. Tidak semua kompetensi dasar dapat diukur dengan penilaian kinerja, penilaian proyek, atau portofolio. Penentuan bentuk penilaian didasarkan pada karakteristik kompetensi keterampilan yang hendak diukur.

Penilaian KI-4 dimaksudkan untuk mengetahui apakah pengetahuan yang sudah dikuasai peserta didik dapat digunakan untuk mengenal dan menyelesaikan masalah dalam kehidupan sesunguhnya (dunia nyata). Penilaian KI-4 menggunakan predikat A (Sangat Baik); B (Baik); C (Cukup); D (Kurang); dan deskripsi. Bentuk penilaian yang digunakan dalam penilaian kompetensi keterampilan IPS di SD sebagai berikut:

a. Penilaian Kinerja

Penilaian kinerja merupakan penilaian yang meminta peserta didik untuk melakukan suatu tugas pada situasi yang sesungguhnya dengan mengaplikasikan atau mendemonstrasikan pengetahuan dan keterampilan yang dibutuhkan. Misalnya dalam pembelajaran IPS, bermain peran, menyajikan laporan hasil pengamatan tentang hubungan sosial masyarakat, dan sebagainya. Pada penilaian kinerja, penekanan penilaiannya dapat dilakukan pada proses dan produk. Penilaian kinerja yang menekankan pada produk disebut penilaian 
produk, sedangkan penilaian kinerja yang menekankan pada proses disebut penilaian unjuk kerja (praktik). Dalam penilaian dibutuhkan rubrik sebagai dasar untuk penilaian.

b. Penilaian Portofolio

Penilaian portofolio adalah penilaian yang dilakukan dengan cara menilai kumpulan seluruh karya peserta didik dalam bidang tertentu yang bersifat reflektif-integratif untuk mengetahui minat, perkembangan, prestasi, dan kreativitas peserta didik dalam kurun waktu tertentu. Penilaian portofolio dilakukan untuk menilai karya-karya peserta didik untuk suatu subtema. Portofolio merupakan bagian dari penilaian autentik, yang dapat menyentuh aspek sikap, pengetahuan, dan keterampilan peserta didik. Bentuk dari portofolio dapat berupa stopma/bantex berisi tugas-tugas tulisan tangan atau karangan siswa, laporan hasil pengamatan, karya-karya dan sebagainya.

c. Penilaian Proyek

Penilaian proyek merupakan kegiatan penilaian terhadap suatu tugas yang harus diselesaikan dalam periode/waktu tertentu. Tugas tersebut berupa rangkaian kegiatan mulai dari perencanaan, pengumpulan data, pengorganisasian, pengolahan dan penyajian data.

\section{CONTOH PENILAIAN PEMBELAJARAN IPS SD KELAS AWAL}

1. Penilaian Kompetensi Sikap

a. Observasi Guru

Contoh format penilaian sikap spiritual (KI-1) oleh guru kelas.

$\begin{array}{ll}\text { Nama Sekolah } & \text { : SD Ceria } \\ \text { Kelas/Semester } & : \text { III/1 } \\ \text { Tahun Pelajaran } & : \text { 2018/2019 } \\ \text { Nama Siswa } & \text { : Raffa }\end{array}$




\begin{tabular}{|c|l|c|l|}
\hline No. & Aspek yang Diamati & Tanggal & Catatan Guru \\
\hline 1. & Berperilaku syukur & $23 / 07 / 2018$ & $\begin{array}{l}\text { Tetap merasa } \\
\text { gembira } \\
\text { walaupun } \\
\text { teman-temannya } \\
\text { mengejek } \\
\text { pakaiannya } \\
\text { sederhana }\end{array}$ \\
\hline 2. & $\begin{array}{l}\text { Berdoa sebelum dan } \\
\text { sesudah kegiatan }\end{array}$ & $16 / 08 / 2018$ & $\begin{array}{l}\text { Mengajak } \\
\text { temannya } \\
\text { berdoa sebelum } \\
\text { bermain sepak } \\
\text { bola }\end{array}$ \\
\hline 3. & Toleransi & $28 / 09 / 2018$ & $\begin{array}{l}\text { Menghormati } \\
\text { temannya yang } \\
\text { sedang } \\
\text { beribadah } \\
\text { walaupun } \\
\text { berbeda agama }\end{array}$ \\
\hline
\end{tabular}

Catatan: Format tersebut dibuat sesuai dengan jumlah siswa dan indikator dapat diganti sesuai dengan kondisi.

Contoh format penilaian sikap sosial (KI-2) oleh guru kelas.

$\begin{array}{ll}\text { Nama Sekolah } & \text { : SD Ceria } \\ \text { Kelas/Semester } & : \text { III/1 } \\ \text { Tahun Pelajaran } & : \text { 2018/2019 } \\ \text { Nama Siswa } & \text { : Raffa }\end{array}$

\begin{tabular}{|l|l|l|l}
\hline No. & Aspek yang Diamati & Tanggal & Catatan Guru
\end{tabular}




\begin{tabular}{|c|l|l|l|}
\hline 1. & Jujur & $13 / 07 / 2018$ & $\begin{array}{l}\text { Kedapatan } \\
\text { berbohong, } \\
\text { mengaku } \\
\text { pekerjaan rumah } \\
\text { dikerjakan } \\
\text { sendiri padahal } \\
\text { dikerjakan oleh } \\
\text { kakaknya }\end{array}$ \\
\hline 2. & Disiplin & $22 / 08 / 2018$ & $\begin{array}{l}\text { Terlambat } \\
\text { mengikuti } \\
\text { upacara }\end{array}$ \\
\hline 3. & Santun & $11 / 10 / 2018$ & $\begin{array}{l}\text { Menyapa guru } \\
\text { ketika bertemu } \\
\text { dan } \\
\text { menyalaminya }\end{array}$ \\
\hline
\end{tabular}

Catatan: Format tersebut dibuat sesuai dengan jumlah peserta didik dan indikator dapat diganti sesuai dengan kondisi.

\section{b. Penilaian Diri}

Penilaian diri merupakan bentuk penilaian dengan cara meminta peserta didik mengemukakan kelebihan dan kekurangan dirinya dalam konteks pencapaian kompetensi. Instrumen yang digunakan berupa lembar penilaian diri. Berikut contoh penilaian diri.

Nama

Kelas/Semester

Waktu Penilaian

Petunjuk: Berilah tanda cek $(\sqrt{ })$ pada kolom "Ya" atau "Tidak" sesuai dengan keadaan yang sebenarnya. 


\begin{tabular}{|c|l|c|c|}
\hline No. & \multicolumn{1}{|c|}{ Pernyataan } & Ya & $\begin{array}{c}\text { Tida } \\
\mathrm{k}\end{array}$ \\
\hline 1. & $\begin{array}{l}\text { Saya berusaha belajar dengan } \\
\text { bersungguh-sungguh }\end{array}$ & & \\
\hline 2. & $\begin{array}{l}\text { Saya mengikuti pembelajaran dengan } \\
\text { penuh perhatian }\end{array}$ & & \\
\hline 3. & $\begin{array}{l}\text { Saya mengerjakan tugas yang diberikan oleh } \\
\text { guru tepat waktu }\end{array}$ & & \\
\hline 4. & Saya berperan aktif dalam kelompok & & \\
\hline 5. & $\begin{array}{l}\text { Saya menghormati dan menghargai orang } \\
\text { tua }\end{array}$ & & \\
\hline 6. & Saya menghormati dan menghargai guru & & \\
\hline & $\ldots . . *^{*}$ & & \\
\hline
\end{tabular}

Keterangan: Tanda (*)pernyataan dapat ditambah sesuai kondisi

\section{c. Penilaian Antarteman}

Penilaian antarteman merupakan bentuk penilaian dengan cara meminta siswa untuk saling menilai terhadap sikap dan perilaku keseharian antarteman. Instrumen yang digunakan berupa lembar penilaian antar siswa. Penilaian antarteman paling baik dilakukan saat peserta didik melakukan kegiatan berkelompok.

Nama

Kelas/Semester

Waktu Penilaian

Petunjuk: Berilah tanda cek $(\sqrt{ })$ pada kolom "Ya" atau "Tidak" sesuai dengan keadaan yang sebenarnya. 


\begin{tabular}{|c|l|c|c|}
\hline No. & \multicolumn{1}{|c|}{ Pernyataan } & Ya & $\begin{array}{c}\text { Tida } \\
\mathrm{k}\end{array}$ \\
\hline 1. & Berperan aktif dalam kelompok & & \\
\hline 2. & $\begin{array}{l}\text { Menghormati dan menghargai pendapat } \\
\text { orang lain }\end{array}$ & & \\
\hline 3. & Mau bekerja sama dalam kelompok & & \\
\hline 4. & Tidak memaksakan kehendak/pendapatnya & & \\
\hline 5. & Mengerjakan tugas yang diberikan & & \\
\hline & $\ldots \ldots{ }^{*}$ & & \\
\hline
\end{tabular}

Keterangan: Tanda $\left({ }^{*}\right)$ pernyataan dapat ditambah sesuai kondisi

2. Penilaian Kompetensi Pengetahuaan

Penilaian terhadap kompetensi pengetahuan dilakukan dengan menggunakan tes tertulis, lisan, dan penugasan dalam bentuk ulangan harian, ulangan tengah semester dengan menggunakan instrumen penilaian (pilihan ganda, isian, menjodohkan, uraian, benar salah).

3. Penilaian Kompetensi Keterampilan

a. Penilaian Praktik

Contoh penilaian praktik pada pembelajaran IPS:

\section{Penilaian Kinerja Mengambar Denah Sekolah}

Kelas/Semester

Pembelajaran

Rubrik

\begin{tabular}{|c|c|c|c|c|}
\hline No. & Aspek & Sangat Baik & Baik & Cukup \\
& & 3 & 2 & 1 \\
\hline
\end{tabular}




\begin{tabular}{|l|l|l|l|l|}
\hline 1. & Hasil gambar & $\begin{array}{l}\text { Bentuk } \\
\text { dasar } \\
\text { terlihat dan } \\
\text { sesuai } \\
\text { dengan } \\
\text { bentuk } \\
\text { denah } \\
\text { sekolah }\end{array}$ & $\begin{array}{l}\text { Bentuk } \\
\text { dasar } \\
\text { terlihat dan } \\
\text { tetapi tidak } \\
\text { sesuai } \\
\text { dengan } \\
\text { bentuk } \\
\text { denah } \\
\text { sekolah }\end{array}$ & $\begin{array}{l}\text { Bentuk } \\
\text { dasar } \\
\text { tidak } \\
\text { terlihat }\end{array}$ \\
\hline 3. & $\begin{array}{l}\text { Ketepatan } \\
\text { arah mata } \\
\text { angin }\end{array}$ & $\begin{array}{l}\text { Arah mata } \\
\text { angin } \\
\text { sesuai }\end{array}$ & $\begin{array}{l}\text { Arah mata } \\
\text { angin } \\
\text { kurang } \\
\text { sesuai }\end{array}$ & $\begin{array}{l}\text { Arah } \\
\text { mata } \\
\text { angin } \\
\text { tidak } \\
\text { sesuai }\end{array}$ \\
\hline
\end{tabular}

Instrumen:

\begin{tabular}{|c|c|c|c|c|c|c|c|}
\hline \multirow{3}{*}{ No. } & \multirow{3}{*}{ Nama } & \multicolumn{6}{|c|}{ Aspek yang Dinilai } \\
\hline & & \multicolumn{3}{|c|}{ Hasil gambar } & \multicolumn{3}{|c|}{ Kerapian } \\
\hline & & 3 & 2 & 1 & 3 & 2 & 1 \\
\hline 1. & & & & & & & \\
\hline 2. & & & & & & & \\
\hline 3. & & & & & & & \\
\hline
\end{tabular}

Skor $=\underline{\text { Skor yang diperoleh }} \times 100$

Skor maksimal

b. Penilaian Portofolio

Portofolio berisi kumpulan produk, kinerja siswa yang dapat mengungkapkan perkembangan kompetensinya. Lembar pertama berupa cover, kemudian lembar kedua berupa format daftar isi, memuat nomor, nama dokumen, tanggal pembuatan, tema/subtema, dan nomor kompetensi terkait. Bagian isi 
portofolio memuat kompetensi yang harus dicapai siswa, kumpulan produk misalnya laporan hasil pengamatan tentang proses terjadinya banjir. Dalam portofolio juga dapat dimasukkan hasil-hasil pembelajaran berbasis proyek yang hasilnya diportofoliokan. Portofolio dapat berupa catatan khusus siswa dalam waktu panjang. Jangka panjang dimaksudkan sebagai catatan khusus guru sejak peserta didik kelas I hingga berlanjut ke jenjang berikutnya.

\section{BAB 7}

\section{KEDUDUKAN IPS SD KELAS AWAL PADA KURIKULUM 2013}

Bab ini berisi materi tentang kedudukan IPS SD Kelas Awal pada Kurikulum 2013. Pembaca yang telah mempelajari materi ini diharapkan mampu:

1. Membedakan pelaksanaan pembelajaran IPS SD Kelas Awal pada KTSP dan Kurikulum 2013

2. Membuat Rencana Pelaksanaan Pembelajaran IPS SD Kelas Awal pada Kurikulum 2013 


\section{A. PEMBELAJARAN IPS PADA KTSP DAN KURIKULUM 2013}

Kurikulum Tingkat Satuan Pendidikan (KTSP) adalah kurikulum operasional yang disusun oleh dan dilaksanakan di masing-masing satuan pendidikan. Dalam Struktur Kurikulum Tingkat Satuan Pendidikan SD memuat 8 mata pelajaran ditambah muatan lokal, yang diantaranya terdapat mata pelajaran IPS.

Kurikulum IPS tahun 2006 cukup sederhana, karena hanya menekankan pada ketercapaian Standar Kompetensi dan Kompetensi Dasar yang dipersyaratkan. Hal ini memberikan peluang pada guru sebagai pengembang kurikulum untuk berkreasi dalam pembelajaran IPS yang aktif, kreatif, efektif, dan menyenangkan.

Materi pelajaran IPS SD merupakan keterpaduan antara materi geografi, sejarah, sosiologi, dan ekonomi. Pelajaran IPS SD pada kelas 1 - 3 dilaksanakan melalui pendekatan tematik, dedangkan pada kelas 4-6 dilaksanakan melalui pendekatan pelajaran.

Mata pelajaran IPS disusun secara sistematis, komprehensif, dan terpadu dalam proses pembelajaran menuju kedewasaan dan keberhasilan dalam kehidupan di masyarakat. Dengan pendekatan tersebut diharapkan anak akan memperoleh pemahaman yang lebih luas dan mendalam pada bidang ilmu yang berkaitan.

esuai dengan karakteristik anak dan IPS SD, maka metode ekspositori akan menyebabkan siswa bersikap pasif, dan menurunkan derajat IPS menjadi pelajaran hafalan yang membosankan. Guru yang bersikap memonopoli peran sebagai sumber informasi, selayaknya 
meningkatkan kinerjanya dengan metode pembelajaran yang bervariasi, seperti menyajikan cooperative learning model; role playing, jigsaw, group investigation, dan lain-lain.

Menerapkan pembelajaran aktif, kreatif, efektif, dan menyenangkan (PAKEM) yang memungkinkan anak mengerjakan kegiatan yang beragam untuk mengembangkan keterampilan, sikap, dan pemahaman dengan penekanan belajar sambil bekerja, sementara guru menggunakan berbagai sumber dan alat bantu belajar, termasuk pemanfaatan lingkungan supaya pembelajaran lebih menarik, menyenangkan, dan efektif. Tentu saja guru harus menimba ilmunya dan melatih keterampilannya, agar ia mampu menyajikan pembelajaran IPS SD dengan menarik.

Pengembangan kurikulum 2013 merupakan langkah lanjutan pengembangan Kurikulum Berbasis Kompetensi yang telah dirintis pada tahun 2004 dan Kurikulum Tingkat Satuan Pendidikan 2006 yang mencakup kompetensi sikap, pengetahuan, dan keterampilan secara terpadu. Pengembangan ini dilakukan untuk menjawab tantangan internal dan eksternal yang berkembang di masyarakat.

Tantangan internal berupa tuntutan pendidikan yang mengacu kepada 8 Standar Nasional Pendidikan yang meliputi Standar Pengelolaan, Standar Biaya, Standar Sarana Prasarana, Standar Pendidik dan Tenaga Kependidikan, Standar Isi, Standar Proses, Standar Penilaian, dan Standar Kompetensi Lulusan. Tantangan internal lainnya terkait dengan faktor perkembangan penduduk Indonesia dilihat dari pertumbuhan penduduk usia produktif.

Tantangan eksternal berupa tantangan masa depan, kompetensi masa depan, persepsi masyarakat, perkembangan pengetahuan dan pedagogi, serta fenomena-fenomena negatif yang mengemuka. Tantangan eksternal antara lain terkait dengan arus globalisasi dan berbagai isu yang terkait dengan masalah lingkungan hidup, kemajuan teknologi dan informasi, kebangkitan industri kreatif dan budaya, serta perkembangan pendidikan di tingkat internasional. 
Arus globalisasi akan menggeser pola hidup masyarakat dari agraris dan perniagaan tradisional menjadi masyarakat industri dan perdagangan modern. Tantangan eksternal juga terkait dengan pergeseran kekuatan ekonomi dunia, pengaruh dan imbas teknosains serta mutu, investasi, dan transformasi bidang pendidikan.

Kurikulum 2013 dikembangkan dengan penyempurnaan pola pikir sebagai berikut:

1. Pola pembelajaran yang berpusat pada guru menjadi pembelajaran berpusat pada peserta didik. Peserta didik harus memiliki pilihan-pilihan terhadap materi yang dipelajari untuk memiliki kompetensi yang sama

2. Pola pembelajaran satu arah (interaksi guru-peserta didik) menjadi pembelajaran interaktif (interaktif guru-peserta didik-masyarakat-lingkungan alam, sumber/ media lainnya)

3. Pola pembelajaran terisolasi menjadi pembelajaran secara jejaring (peserta didik dapat menimba ilmu dari siapa saja dan dari mana saja yang dapat dihubungi serta diperoleh melalui internet)

4. Pola pembelajaran pasif menjadi pembelajaran aktif-mencari (pembelajaran siswa aktif mencari semakin diperkuat dengan model pembelajaran pendekatan sains)

5. Pola belajar sendiri menjadi belajar kelompok (berbasis tim)

6. Pola pembelajaran alat tunggal menjadi pembelajaran berbasis alat multimedia

7. Pola pembelajaran berbasis massal menjadi kebutuhan pelanggan (users) dengan memperkuat pengembangan potensi khusus yang dimiliki setiap peserta didik

8. Pola pembelajaran ilmu pengetahuan tunggal (monodiscipline) menjadi pembelajaran ilmu pengetahuan jamak (multidisciplines)

9. Pola pembelajaran pasif menjadi pembelajaran kritis. 
Sedangkan untuk karakteristiknya, kurikulum 2013 dirancang dengan karakteristik sebagai berikut:

1. Mengembangkan keseimbangan antara pengembangan sikap spiritual dan sosial, rasa ingin tahu, kreativitas, kerja sama dengan kemampuan intelektual dan psikomotorik

2. Sekolah merupakan bagian dari masyarakat yang memberikan pengalaman belajar terencana dimana peserta didik menerapkan apa yang dipelajari di sekolah ke masyarakat dan memanfaatkan masyarakat sebagai sumber belajar

3. Mengembangkan sikap, pengetahuan, dan keterampilan serta menerapkannya dalam berbagai situasi di sekolah dan masyarakat

4. Memberi waktu yang cukup leluasa untuk mengembangkan berbagai sikap, pengetahuan, dan keterampilan

5. Kompetensi dinyatakan dalam bentuk kompetensi inti kelas yang dirinci lebih lanjut dalam kompetensi dasar matapelajaran

6. Kompetensi inti kelas menjadi unsur pengorganisasi (organizing elements) kompetensi dasar, dimana semua kompetensi dasar dan proses pembelajaran dikembangkan untuk mencapai kompetensi yang dinyatakan dalam kompetensi intikompetensi dasar dikembangkan didasarkan pada prinsip akumulatif, saling memperkuat (reinforced) dan memperkaya (enriched) antarmatapelajaran dan jenjang pendidikan (organisasi horizontal dan vertikal).

Kurikulum 2013 bertujuan untuk mempersiapkan manusia Indonesia agar memiliki kemampuan hidup sebagai pribadi dan warga negara yang beriman, produktif, kreatif, inovatif, dan afektif serta mampu berkontribusi pada kehidupan bermasyarakat, berbangsa, bernegara, dan peradaban dunia. Dalam kurikulum 2013 posisi guru tidak hanya sebagai pengajar dan pendidik seperti yang 
telah kita kenal bersama, namun di kurikulum ini posisi guru juga sebagai fasilitator, leader, dan motivator.

Jika pada kurikulum sebelumnya mata pelajaran IPA dan IPS berdiri sendiri, dalam kurikulum 2013 ini keduanya menjadi materi pembahasan pada semua pelajaran. Dalam artian, dua mata pelajaran ini diintegrasikan ke dalam semua mata pelajaran. Untuk IPA, misalnya, akan menjadi materi pembahasan pelajaran Bahasa Indonesia dan matematika, sedangkan untuk IPS akan menjadi pembahasan materi pelajaran Bahasa Indonesia dan Pendidikan Kewarganegaraan (PKn).

Pengembangan pembelajaran IPS dapat diintegrasikan dengan pembelajaran bahasa Indonesia dan PPKn. Meski pada kurikulum 2013 tidak terdapat mata pelajaran IPS, tidak berarti muatan materinya hilang. Muatan materi IPS tetap diajarkan kepada siswa, hanya saja terintegrasi pada pembelajaran dengan pembahasan bahasa Indonesia dan PPKn. 


\section{BIODATA PENULIS}

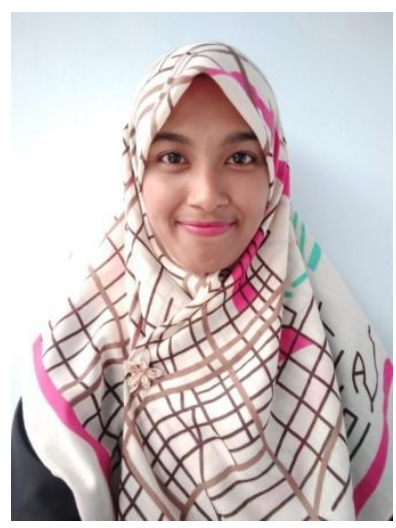

Penulis lahir di Sidoarjo, 15 Februari 1993.

Tahun 2014 penulis menyelesaikan studi S1 Pendidikan Guru Sekolah Dasar di Universitas Negeri Malang. Penulis kemudian melanjutkan studi magister pendidikan dasar di universitas yang sama dan lulus pada tahun 2016. Saat ini penulis tercatat sebagai dosen PGSD di Universitas Muhammadiyah Sidoarjo. Untuk menghubungi penulis bisa melalui email ke alamat suuphierhero@yahoo.com atau DM instagram@suuphierhero. 


\section{DAFTAR PUSTAKA}

Akbar, S. 2015. Instrumen Perangkat Pembelajaran. Bandung:

Remaja Rosdakarya.

Akbar, S., dkk. 2016. Implementasi Pembelajaran Tematik di Sekolah Dasar. Bandung: Remaja Rosdakarya.

Arikunto, S. 2015. Dasar-Dasar Evaluasi Pendidikan. Jakarta: Bumi Aksara.

Basuki, I., dan Hariyanto. 2014. Asesmen Pembelajaran. Bandung: Rosda.

Bruce and Joyce. 1986. Models of Teaching. New Jersey: Prentice Hall International.

Carin, A.A. \& Sund, R.B. (1989). Teaching Science Through Discovery. Columbus: Merrill Publishing Company.

Dale, E. 1969. Audiovisual Methods in Teaching. New York: The Dryden Press, Holt, Rinehart and Winston, Inc.

Desmita. 2012. Psikologi Perkembangan Siswa. Bandung: Remaja Rosdakarya.

Djamarah, S. B., dan Zain, A. 2010. Strategi Belajar Mengajar. Jakarta: Rineka Cipta.

Djemari Mardapi. 2011. Teknik Penyusunan Instrumen Tes dan Non Tes. Yogyakarta: Mitra Cendekia.

Gerlach, V. G. dan Ely, D.P. 1971. Teaching and Media: A Systematic Approach. Eaglewood Cliffs: Prentice Hall, Inc. 
Good, R. G. (1977). How Children Learn Science. New York: Macmillan Publishing Co.

Hamalik, Oemar. 1994. Media Pendidikan. Bandung: Penerbit PT. Citra Aditya Bakti.Levie, W. Howard dan Levie, Diane. 1975. Pictorial Memory Processes. AVCR Vol 23 No. 1 Spring 1975. Harsiati, T. 2011. Penilaian dalam Pembelajaran. Malang: UM Press. Ishack, S. U., dkk. 2009. Pendidikan IPS di SD. Jakarta: Universitas Terbuka.

Istarani. 2012. 58 Model Pembelajaran Inovatif. Medan: Media Persada.

Johnson, E. B. 2006. Contextual Teaching and Learning: What it Is and Why It Is Here to Stay. California USA: Corwin Press. Inc. La Maronta Galib. (1992). Studi Terhadap Kemampuan Berpikir Anak Usia Sekolah Dasar Dalam Konservasi Kuantitas Dan Berat Pada Empat Sekolah Dasar Negeri Di Kota Administratif Kendari Dan Tiga Sekolah Dasar Negeri Di Pulau Siompu Kabupaten Buton Propinsi Sulawesi Tenggara. Tesis PPS IKIP Bandung: tidak diterbitkan.

Majid, A. 2014. Pembelajaran Tematik Terpadu. Bandung: Remaja Rosdakarya.

Prastowo, A. 2013. Pengembangan Bahan Ajar Tematik. Jogjakarta: Diva Press.

Prastowo, A. 2015. Panduan Kreatif Membuat Buku Teks Inovatif. Jogjakarta: Diva Press.

Pitadjeng. 2006. Pembelajaran Matematika yang Menyenangkan. Jakarta: Departemen Pendidikan Nasional.

Sanjaya, W. 2011. Strategi Pembelajaran Berorientasi Standar Proses Pendidikan. Jakarta: Penerbit Kencana.

Smaldino, S. E., Lowther, D. L., \& Russel, J. D. 2008. Instructional Technology and Media For Learning. USA: Pearson.

Suparman, M. A. 2014. Desain Instruksional Modern. Jakarta:

Penerbit Erlangga. 
Susanto, A. 2014. Pengembangan Pembelajaran IPS di Sekolah Dasar. Jakarta: Penerbit Kencana.

Widoyoko, E. P. 2014. Penilaian Hasil Pembelajaran di Sekolah. Yogyakarta: Pustaka Pelajar.

Woolfolk, A. E. \& Nicolich, L. M. (1980). Educational Psychology for Teachers. New Jersey: Prentice Hall Inc. 